\title{
The Gela Basin pockmark field in the strait of Sicily (Mediterranean Sea): chemosymbiotic faunal and carbonate signatures of postglacial to modern cold seepage
}

\author{
M. Taviani ${ }^{1,2}$, L. Angeletti ${ }^{1}$, A. Ceregato ${ }^{1}$, F. Foglini $^{1}$, C. Froglia ${ }^{3}$, and F. Trincardi ${ }^{1}$ \\ ${ }^{1}$ ISMAR-CNR Istituto di Scienze Marine, Via Gobetti 101, 40129, Bologna, Italy \\ ${ }^{2}$ Woods Hole Oceanographic Institution, 266 Woods Hole Rd, Woods Hole, Ma. 02543, USA \\ ${ }^{3}$ ISMAR-CNR Istituto di Scienze Marine, Largo Fiera della Pesca 2, 60125, Ancona, Italy \\ Correspondence to: M. Taviani (marco.taviani@bo.ismar.cnr.it)
}

Received: 10 December 2012 - Published in Biogeosciences Discuss.: 22 January 2013

Revised: 24 April 2013 - Accepted: 23 May 2013 - Published: 12 July 2013

\begin{abstract}
The geo-biological exploration of a pockmark field located at ca. $800 \mathrm{~m}$ below sea level in the Gela basin (Strait of Sicily, Central Mediterranean) provided a relatively diverse chemosymbiotic community and methane-imprinted carbonates. To date, this is the first occurrence of such a type of specialised deep-water cold-seep communities recorded from this key region, before documented in the Mediterranean as rather disjunct findings in its eastern and westernmost basins. The thiotrophic chemosymbiotic organisms recovered from this area include empty tubes of the vestimentiferan Lamellibrachia sp., loose and articulated shells of lucinids (Lucinoma kazani, Myrtea amorpha), vesicomyids (Isorropodon perplexum), and gastropods (Taranis moerchii). A callianassid decapod (Calliax sp.) was consistently found alive in large numbers in the pockmark mud. Their post-mortem calcified parts mixed with molluscs and subordinately miliolid foraminifers form a distinct type of skeletal assemblage. Carbonate concretions display $\delta^{13} \mathrm{C}$ values as low as $-40 \%$ PDB suggesting the occurrence of light hydrocarbons in the seeping fluids. Since none of the truly chemosymbiotic organisms was found alive, although their skeletal parts appear at times very fresh, some specimens have been AMS $-{ }^{14} \mathrm{C}$ dated to shed light on the historical evolution of this site. Lamellibrachia and Lucinoma are two of the most significant chemosymbiotic taxa reported from various Mediterranean cold seep sites (Alboran Sea and Eastern basin). Specimens from station MEDCOR78 (pockmark\#1, Lat. $36^{\circ} 46^{\prime} 10.18^{\prime \prime} \mathrm{N}$, Long. $14^{\circ} 01^{\prime} 31.59^{\prime \prime} \mathrm{E}, 815 \mathrm{~m}$ below sea level) provided ages of $11736 \pm 636 \mathrm{yr}$ cal BP (Lamelli-
\end{abstract}

brachia sp.), and $9609.5 \pm 153.5 \mathrm{yr}$ cal BP (L. kazani). One shell of $M$. amorpha in core MEDCOR81 (pockmark\#6, Lat $36^{\circ} 45^{\prime} 38.89^{\prime \prime} \mathrm{N}$, Long $14^{\circ} 00^{\prime} 07.58^{\prime \prime} \mathrm{E}, 822 \mathrm{~m}$ below sea level) provided a sub-modern age of $484 \pm 54 \mathrm{yrcal} \mathrm{BP}$. These ages document that fluid seepage at this pockmark site has been episodically sustaining thiotrophic macrobenthic communities since the end of the Younger Dryas stadial up to sub-recent times.

\section{Introduction}

Pockmarks are circular to sub-elliptical crater-like depressions of variable size (few to many hundreds of metres in diameter) and depth (up to few tens $\mathrm{m}$ ) typically due to degassing of fluids through fine-grained unconsolidated marine sediment under a variety of geologic scenarios (King and McLean, 1970; Hovland, 1989, 1992; Scanlon and Knebel, 1989; Kelley et al., 1994; Gay et al., 2003; Trincardi et al., 2004; Paull et al., 2007). Pockmarks often occur in clusters and cover wide areas, representing a common and widespread feature on the continental margins worldwide (Hovland and Judd, 1988). They receive much attention especially because escaping fluids are often hydrocarbonenriched venues in the form of slow seepage, vigorous venting or even eruptions, at times representing a distinct geohazard for offshore constructions and navigation (Newton et al., 1980; Hovland, 1987; Curzi et al., 1988; Curzi, 2012). Such fluid releases are also considered as a potential co-actor 


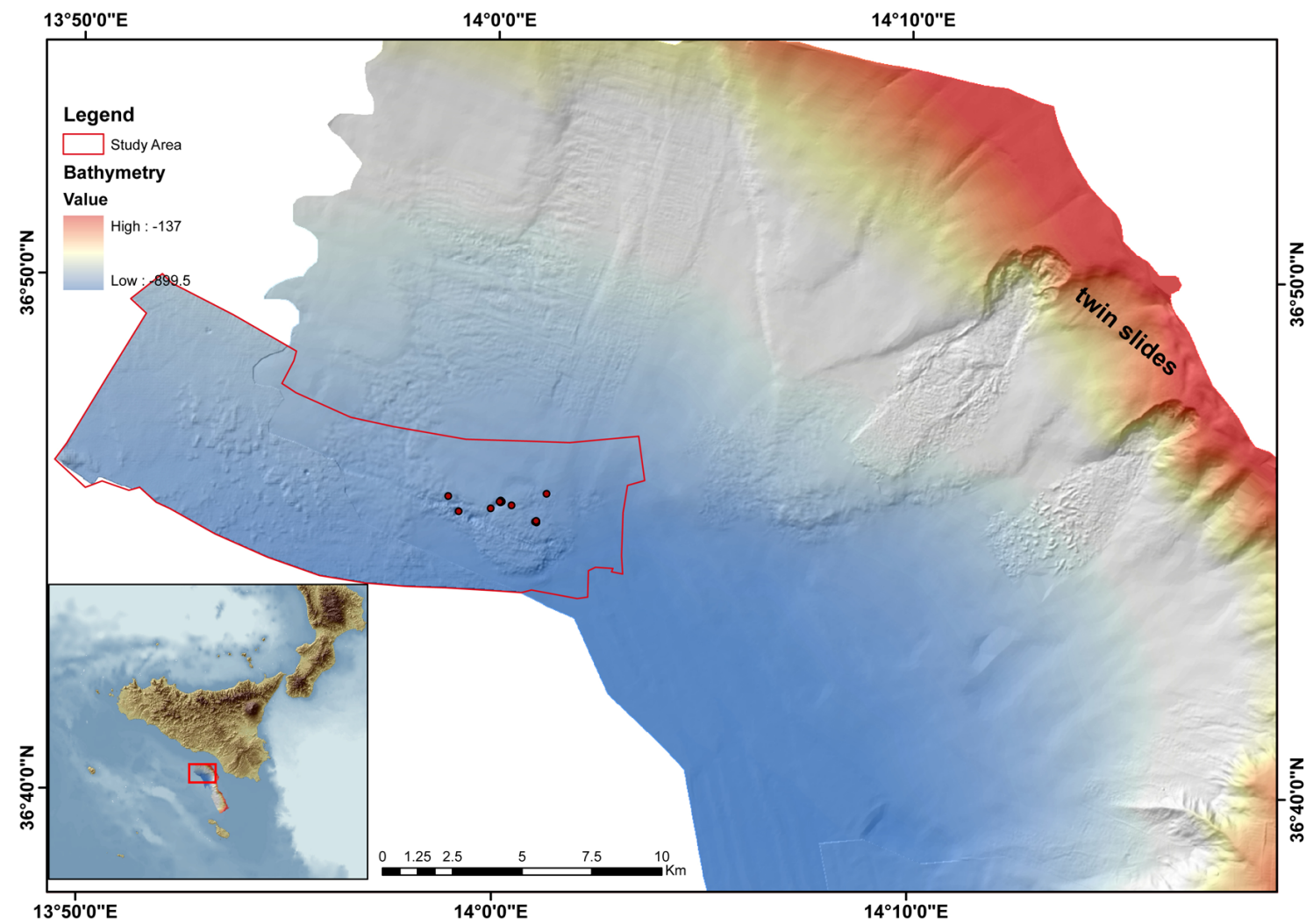

Fig. 1. Map showing the shaded relief Digital Terrain Model (DTM of $20 \mathrm{~m}$ resolution with $10 \times$ vertical exaggeration) of the Gela Basin in the Strait of Sicily. The figure illustrates the location of the pockmarks field discussed in this article (red spots represents major pockmarks); inset, the Mediterranean basin with rectangle showing the same area magnified in the figure.

in triggering mass-sediment failure along continental margins, in conjunction with sea level changes or earthquakes (Minisini and Trincardi, 2009). Pockmarks are known to host at times peculiar biota in response to nature of escaping fluids, rate of emissions, seepage resilience and water depth (Hovland and Thomsen, 1989; Hovland and Judd, 1988; Taviani, 2011, 2013). Gas charged sediments may in fact sustain microbiological communities operating on common compounds in fluids, i.e. hydrogen sulphide and hydrocarbons like methane (Cavanaugh et al., 2006; Dando, 2001; Duperron, 2010). In turn, such communities could be exploited by specialized metazoans through complex symbiotic relationships (see MacDonald et al., 1990; Olu-Le Roy et al., 2007; Taviani, 2001; Duperron, 2010, with references). Pockmarks are also sites were methane-related authigenic carbonates could be generated (Hovland et al., 1987; Hovland and Judd, 1988; Gontharet et al., 2007).

In the frame of the EU Hermes and Hermione projects, the Strait of Sicily in the central Mediterranean was targeted as a key area to study sediment instability processes that affect continental margins. During such exploration a field of pockmarks was charted and sampled in detail off the southern margin of Sicily (Fig. 1). Here we present first data on deep sea pockmarks in the Gela basin resulting in novel in- formation about resident chemosymbiotic communities, biosedimentological processes, authigenic carbonates and seepage temporal variability in this sector of the Mediterranean Sea connecting its western and eastern basins.

\section{Material and methods}

The study area was surveyed during cruises HERMES05 (July 2005), MEDCOR and DECORS December 2009 and August 2011, respectively, of R/V Urania. Swath bathymetry data were acquired using a Kongsberg Simrad EM710 multibeam echosounder with a nominal sonar frequency of $70-100 \mathrm{kHz}$ an angular coverage sector of $140^{\circ}$, a beam width of $1^{\circ} \times 1^{\circ}$ and 800 soundings per ping in dual mode. Chirp-sonar profiles were obtained using a hull-mounted sixteen-transducer source with a sweep modulated $2-7 \mathrm{kHz}$ outgoing signal equivalent to a $3.5 \mathrm{kHz}$ profile.

Bottom samplings were performed using a 1.2 ton gravity corer, large volume grab and epibenthic hauls (Table 1).

Water-column attributes were measured with a Conductivity/Temperature/Depth profiler (CTD) using a Seabird SBE 11 PLUS employing the SEASAVE V5.33 software. 
Table 1. Sampling station list of Cruises MEDCOR and DECORS in the Gela Basin.

\begin{tabular}{|c|c|c|c|c|c|c|c|c|}
\hline Station & Date & $\begin{array}{c}\text { Start Lat. } \\
\text { GGMMSS.XX }\end{array}$ & $\begin{array}{l}\text { Start Long. } \\
\text { GGMMSS.XX }\end{array}$ & End Lat. & End Long. & $\begin{array}{l}\text { Start } \\
\text { depth }\end{array}$ & $\begin{array}{l}\text { End } \\
\text { depth }\end{array}$ & Gear \\
\hline MEDCOR-68 & 19 Dec 2009 & $36^{\circ} 45^{\prime} 38.24^{\prime \prime}$ & $14^{\circ} 00^{\prime} 09.02^{\prime \prime}$ & & & 820.0 & & CTD \\
\hline MEDCOR-69 & 19 Dec 2009 & $36^{\circ} 45^{\prime} 37.83^{\prime \prime}$ & $14^{\circ} 00^{\prime} 08.20^{\prime \prime}$ & & & 824.0 & & Grab \\
\hline MEDCOR-70 & 19 Dec 2009 & $36^{\circ} 45^{\prime} 16.42^{\prime \prime}$ & $14^{\circ} 01^{\prime} 01.07^{\prime \prime}$ & & & 840.8 & & Gravity Core \\
\hline MEDCOR-71 & 19 Dec 2009 & $36^{\circ} 45^{\prime} 16.07^{\prime \prime}$ & $14^{\circ} 00^{\prime} 58.79^{\prime \prime}$ & $36^{\circ} 45^{\prime} 35.00^{\prime \prime}$ & $14^{\circ} 00^{\prime} 10.82^{\prime \prime}$ & 840.0 & 820.0 & $\begin{array}{l}\text { Epibenthic } \\
\text { modified haul }\end{array}$ \\
\hline MEDCOR-72 & 19 Dec 2009 & $36^{\circ} 45^{\prime} 15.11^{\prime \prime}$ & $14^{\circ} 01^{\prime} 01.18^{\prime \prime}$ & $36^{\circ} 45^{\prime} 15.69^{\prime \prime}$ & $14^{\circ} 01^{\prime} 00.61^{\prime \prime}$ & 842.0 & 840.6 & CTD (POM) \\
\hline MEDCOR-74 & 19 Dec 2009 & $36^{\circ} 45^{\prime} 38.82^{\prime \prime}$ & $14^{\circ} 00^{\prime} 10.35^{\prime \prime}$ & $36^{\circ} 44^{\prime} 30.7^{\prime \prime}$ & $13^{\circ} 58^{\prime} 48.06^{\prime \prime}$ & 824.0 & 850.0 & $\begin{array}{l}\text { Epibenthic } \\
\text { modified haul }\end{array}$ \\
\hline MEDCOR-75 & 21 Dec 2009 & $36^{\circ} 45^{\prime} 48.41^{\prime \prime}$ & $14^{\circ} 01^{\prime} 15.29^{\prime \prime}$ & & & 833.0 & & Grab \\
\hline MEDCOR-76 & 21 Dec 2009 & $36^{\circ} 45^{\prime} 34.56^{\prime \prime}$ & $14^{\circ} 00^{\prime} 24.85^{\prime \prime}$ & & & 820.2 & & Grab \\
\hline MEDCOR-77 & 21 Dec 2009 & $36^{\circ} 45^{\prime} 44.57^{\prime \prime}$ & $13^{\circ} 58^{\prime} 52.79^{\prime \prime}$ & & & 831.7 & & Grab \\
\hline MEDCOR-78 & 21 Dec 2009 & $36^{\circ} 45^{\prime} 40.13^{\prime \prime}$ & $14^{\circ} 00^{\prime} 08.90^{\prime \prime}$ & $36^{\circ} 46^{\prime} 10.18^{\prime \prime}$ & $14^{\circ} 01^{\prime} 31.59^{\prime \prime}$ & 815.0 & 811.0 & $\begin{array}{l}\text { Epibenthic } \\
\text { modified haul }\end{array}$ \\
\hline MEDCOR-80 & 19 Dec 2009 & $36^{\circ} 45^{\prime} 31.18^{\prime \prime}$ & $13^{\circ} 59^{\prime} 54.57^{\prime \prime}$ & $36^{\circ} 45^{\prime} 40.10^{\prime \prime}$ & $13^{\circ} 59^{\prime} .49 .79^{\prime \prime}$ & 820.0 & 815.0 & $\begin{array}{l}\text { Epibenthic } \\
\text { modified haul }\end{array}$ \\
\hline MEDCOR-81 & 19 Dec 2009 & $36^{\circ} 45^{\prime} 37.84^{\prime \prime}$ & $14^{\circ} 00^{\prime} 08.21^{\prime \prime}$ & & & 832.0 & & Gravity Core \\
\hline MEDCOR-82 & 19 Dec 2009 & $36^{\circ} 45^{\prime} 16.28^{\prime \prime}$ & $14^{\circ} 01^{\prime} 01.08^{\prime \prime}$ & & & 840.9 & & Grab \\
\hline DECORS-48 & 8 Aug 2011 & $36^{\circ} 46^{\prime} 16.86^{\prime \prime}$ & $14^{\circ} 00^{\prime} 06.80^{\prime \prime}$ & & & 816.0 & & CTD \\
\hline DECORS-49 & 8 Aug 2011 & $36^{\circ} 45^{\prime} 39.24^{\prime \prime}$ & $14^{\circ} 00^{\prime} 06.64^{\prime \prime}$ & & & 818.0 & & Grab \\
\hline DECORS-50 & 9 Aug 2011 & $36^{\circ} 46^{\prime} 16.86^{\prime \prime}$ & $13^{\circ} 55^{\prime} 28.42^{\prime \prime}$ & & & 827.0 & & Grab \\
\hline
\end{tabular}

Stable isotope analyses were performed at the Mass Spectrometry Laboratory of the CNR-IGG (Institute for Geosciences and Earth Resources) Pisa, using a FinniganMAT252 mass-spectrometer. The carbonate samples were cleansed, powdered and then analysed following standard procedures by reacting carbonate aliquots with $100 \%$ orthophosphoric acid under vacuum. Results are expressed as $\%$ relative to VPDB (Vienna-Pee Dee Belemnite) standard by assigning a value of $+1.95 \% \circ\left({ }^{13} \mathrm{C}\right)$ and a value of $-2.2 \%$ o $\left({ }^{18} \mathrm{O}\right)$ exactly to NBS 19 calcite; the analytical error is $\pm 0.1 \delta$ (Table 2).

${ }^{14} \mathrm{C}$-AMS dating was carried out at the Poznán Radiometric Laboratory, Poland (Table 3).

\section{The pockmark field of Gela}

Pockmarks are common features at many continental margins in the Mediterranean basin (Stefanon, 1981; Stefanon et al., 1983; Curzi and Veggiani, 1985; Mazzotti et al., 1987; Hovland and Curzi, 1989; Trincardi et al., 2004; Geletti et al., 2008; Coleman et al., 2012; Curzi, 2012; Somoza et al., 2012). They have been recently documented also in various locations of the Strait of Sicily, although most published studies regard relatively shallow-water (ca. 70-200 m) occurrences (Savini et al., 2009; Cangemi et al., 2010; Micallef et al., 2011). Pockmarks do occur in the Gela basin at bathyal depths (Minisini and Trincardi, 2009, this paper).

Gela basin is the Plio-Quaternary foredeep of the Maghrebian fold-and-thrust belt and is a site of widespread and repeated mass transport. Gela Slide, the largest mass trans- port complex in the area, has affected the northern margin of the basin mobilising a volume of sediment in the order of $1000 \mathrm{~km}^{3}$ in mid-Pleistocene times (Trincardi and Argnani, 1990). Following this major basin-wide event, several smaller-scales mass failure events impacted the area up to the Holocene (Minisini et al., 2007) and with recurrence intervals in the order of a few thousands of years between successive events (Minisini and Trincardi, 2009). The most recent mass-transport events involved, in various mixes, two basic distinctive kinds of slope sediments: the Pleistocene clinoforms that prograde with increasing slope angle and outbuilding the shelf seaward; and upper Pleistocene to Holocene muddy contourite deposits characterised by watersaturated and poorly consolidated sediment (Verdicchio and Trincardi, 2008). In all cases where stacked MTD deposits appear sandwiched within basin-wide draped units, the latter units appear disrupted by vertical features that have been ascribed to fluid-escape features from MTDs that became rapidly buried and perhaps pressurized (Minisini and Trincardi, 2009).

The Gela basin pockmark field (GBPF) is located in the Strait of Sicily, ca. $20 \mathrm{~nm}$ offshore the southern coast of Sicily in a depth range of 800-900 m (Fig. 1). Firstly detected upon TOBI side scan sonar in 2003 and by low-resolution multibeam bathymetric data in 2005, the GBPF was then surveyed more in detail in winter 2009 and again in summer 2011 during Hermione cruise DECORS when high resolution multibeam data were acquired, and additional pockmark fields further west, identified. 
Table 2. Stable Isotopes Analysis expressed in the conventional $\delta$ notation relative to the Vienna-Pee Dee Belemnite (VPDB) reference standard.

\begin{tabular}{|c|c|c|c|c|c|c|}
\hline Sample & Material & Species & $\begin{array}{l}{ }^{13} \mathrm{C} \delta \% \\
\text { vs PDB }\end{array}$ & $\sigma^{13} \mathrm{C}$ & $\begin{array}{r}{ }^{18} \mathrm{O} \delta \% \\
\text { vs PDB }\end{array}$ & $\sigma^{18} \mathrm{O}$ \\
\hline MEDCOR70 & Shell & Lucinoma kazani & 0.82 & \pm 0.1 & 2.71 & \pm 0.1 \\
\hline MEDCOR78 & Shell & Isorropodon perplexum & 2.66 & \pm 0.1 & 2.48 & \pm 0.1 \\
\hline MEDCOR81 & Shell & Myrtea amorpha & -1.23 & \pm 0.1 & 2.33 & \pm 0.1 \\
\hline MEDCOR81 & Shell & Isorropodon perplexum & 0.16 & \pm 0.1 & 2.21 & \pm 0.1 \\
\hline MEDCOR81 & Claw & Calliax sp. & -1.84 & \pm 0.1 & 3.23 & \pm 0.1 \\
\hline MEDCOR70 & Mudstone & & -40.77 & \pm 0.1 & 4.98 & \pm 0.1 \\
\hline MEDCOR78 & Lithified burrow & & -4.05 & \pm 0.1 & 3.18 & \pm 0.1 \\
\hline MEDCOR78 & Carbonate concretion on shell & Lucinoma kazani & -37.57 & \pm 0.1 & 2.86 & \pm 0.1 \\
\hline
\end{tabular}

Table 3. Radiocarbon data from the Poznán Radiocarbon Laboratory in Poznán, Poland. Radiocarbon years $\left({ }^{14} \mathrm{C}-\mathrm{yr}\right)$ correspond to the true half-life. Calibrated age ranges reflect the $95.4 \%$ probability window ( $2 \sigma$-error) and were calculated with Calib6.0.1, using the surface marine calibration curve MARINE09 by Reimer et al. (2009).

\begin{tabular}{lllccccc}
\hline Code \# & Sample & Species & $\begin{array}{c}\text { Radiocarbon Age } \\
(14 \text { C-yr BP })\end{array}$ & $\begin{array}{c}\text { Delta } R \\
(\mathrm{yr})\end{array}$ & $\begin{array}{c}\text { Two- } \sigma \text { ranges } \\
(\mathrm{yr} \text { cal BP })\end{array}$ & $\begin{array}{c}\text { Age cal BP } \\
(\mathrm{yr} \text { cal BP })\end{array}$ & $\begin{array}{c}\text { Calibration } \\
\text { data }\end{array}$ \\
\hline Poz-38025 & MEDCOR78 & Lamellibrachia sp. & $10500 \pm 200$ & $41 \pm 7$ & $11121-12343$ & $11732 \pm 611$ & Marine09 \\
Poz-37995 & MEDCOR78 & Lucinoma kazani & $8960 \pm 60$ & $41 \pm 7$ & $9456-9763$ & $9610 \pm 154$ & Marine09 \\
Poz-55055 & MEDCOR78 & Isorropodon perplexum & $7920 \pm 50$ & $41 \pm 7$ & $8082-8583$ & $8333 \pm 250$ & Marine09 \\
Poz-55053 & MEDCOR69 & Taranis moerchii & $7820 \pm 130$ & $41 \pm 7$ & $7901-8589$ & $8245 \pm 344$ & Marine09 \\
Poz-37994 & MEDCOR81 & Myrtea amorpha & $1090 \pm 30$ & $41 \pm 7$ & $547-669$ & $486 \pm 54$ & Marine09 \\
\hline
\end{tabular}

The resulting detailed morpho-bathymetric map documents the existence of discrete clusters of pockmarks in a restricted sector of the Gela basin (Figs. 1-4). Our data do not show any clear preferential orientation of these features. All pockmarks in the studied field are clustered in seven seafloor patches for a total area of about $18 \mathrm{~km}^{2}$. The pockmarks presents generally a sub-circular shape, with the exception of the pockmark \#1 (Fig. 2) which is elliptical shaped, and range in diameter from 40 to $310 \mathrm{~m}$, although most of them are between 40 and $100 \mathrm{~m}$ and only 11 (Fig. 2) are between $200 \mathrm{~m}$ and $310 \mathrm{~m}$. The bottom of some of these is as much as $20 \mathrm{~m}$ below the surrounding seafloor; most however are less then $6 \mathrm{~m}$ deep. In a cross section, extracted from the bathymetric profile, the pockmarks in most cases appear to be U-shaped; but four of them are V-shaped and (Fig. 2) show a positive relief ranging from $4 \mathrm{~m}$ to $7 \mathrm{~m}$ along their rim. The side slope ranges from $7^{\circ}$ to $13^{\circ}$ reaching a maximum of $16^{\circ}$. The regional surrounding slope is about $2-3^{\circ}$. Width to depth ratio were calculated for 11 pockmarks from bathymetric profiles crossed near the feature centres. The ratio fell between $11: 1$ and $40: 1$ with most near $18: 1$. There is not consistent relation between this ratio and relative size of the pockmark.

Noticeably, acoustic signals relatable to the presence of gas entrapped in the sediment (such as BSR) or to active degassing (plumes) were not detected during both surveys (Fig. 5). Furthermore, CTD profiles show no $T-S$ anomalies.
The largest depression with an internal bulge, resulting from the coalescence of two pockmarks, was selected as the prime target for bottom sampling. The entire area is a fishing ground subjected for many years to a peculiar local fishing (mal)practice known as cannizzi that litters the bottom by leaving behind scores of dead weights with long plastic threads attached (Taviani, 2010). Before proceeding with grab and core sampling, and CTD casting, it was therefore necessary to clear first the bottom by removing this litter. This goal was achieved by using a small modified haul that in fact successfully entangled some such cannizzi remains (threads and some weights), the former intensely over grown by live cold water corals. A second trawl on the same trajectory intercepted the bottom collecting many dead shells of Lucinoma clams and tubeworms, living ghost shrimps and a few carbonate concretions amidst other benthic organisms and litter (Fig. 7a). Only at this stage, this large pockmark and some other pockmarks in the area were tested with grab sampling and coring, integrating the exploration with CTD casts. Additional bottom samples were acquired in 2011 and on this occasion other pockmarks were also sampled.

\section{Fauna}

The living component in the benthic macro-and megafauna inside the pockmarks at the time of sampling was rather scarce and mostly represented by sparse bivalves 


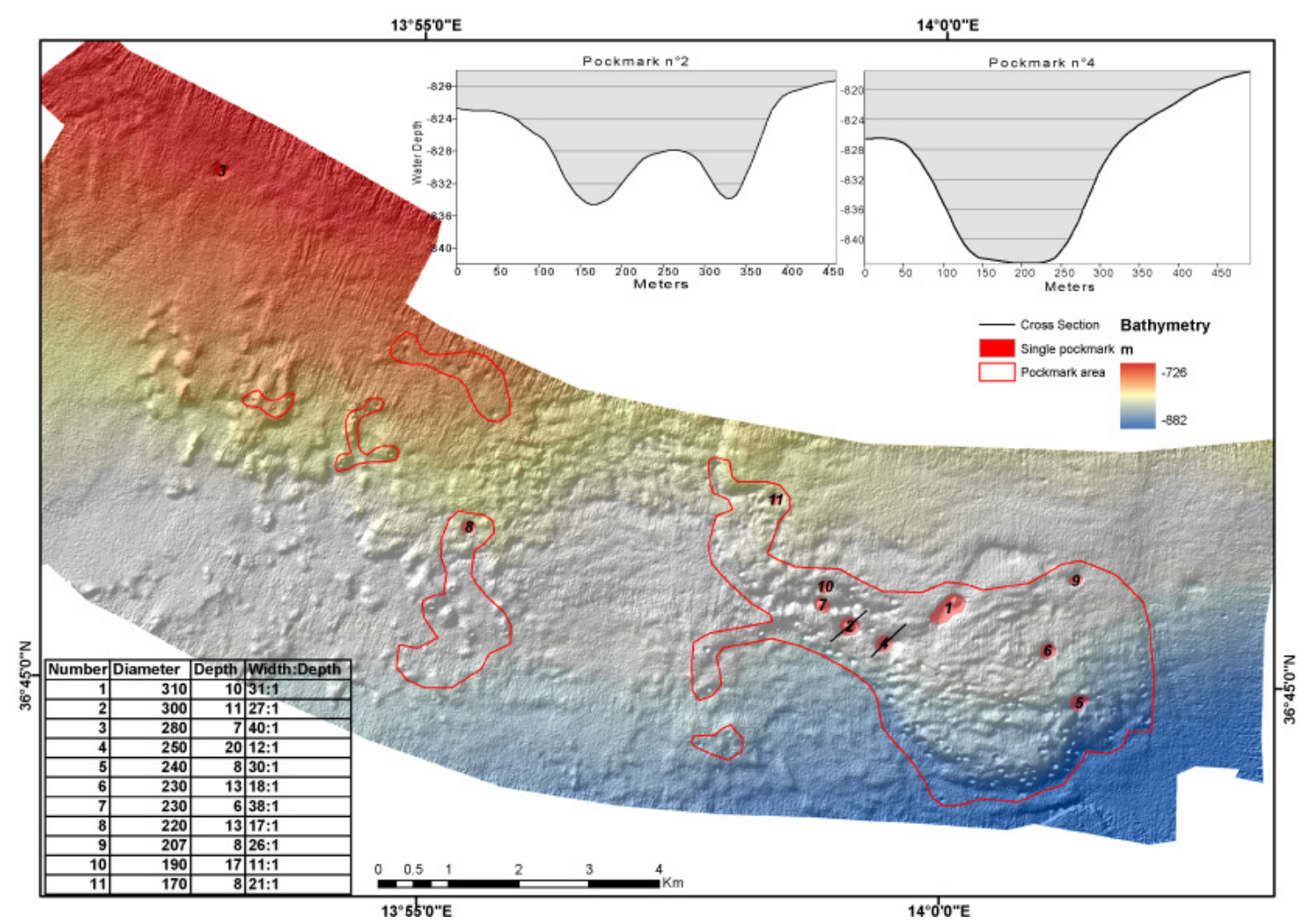

Fig. 2. Shaded relief DTM of the study area $(5 \mathrm{~m}$ resolution and $10 \times$ vertical exaggeration) showing the complex, rough topography punctuated by many sub-circular depressions interpreted as pockmarks. The 11 major pockmarks, with diameters greater than $200 \mathrm{~m}$, are numbered from maximum to minimum dimension. Their geo-morphometric characteristics are listed in the table; the bathymetric profiles show the cross section of two main pockmarks showing the different internal geometry, respectively U-shaped and V-shaped with internal positive relief. Furthermore, the image reveals that the major pockmark (Number 1) is formed by two partly coalescent depressions.

Table 4. List of major established (chemosymbiotic bivalves, and tubeworm) and putative (gastropods, callianassid) metazoans associated with pockmark cold seepage at the GBPF.

\begin{tabular}{|c|c|c|c|c|c|c|c|c|}
\hline & $\begin{array}{c}\text { MEDCOR } \\
69\end{array}$ & $\begin{array}{c}\text { MEDCOR } \\
71\end{array}$ & $\begin{array}{c}\text { MEDCOR } \\
76\end{array}$ & $\begin{array}{c}\text { MEDCOR } \\
78\end{array}$ & $\begin{array}{c}\text { MEDCOR } \\
80\end{array}$ & $\begin{array}{c}\text { MEDCOR } \\
\quad 82\end{array}$ & $\begin{array}{c}\text { DECORS } \\
49\end{array}$ & $\begin{array}{c}\text { DECORS } \\
50\end{array}$ \\
\hline $\begin{array}{l}\text { Lucinoma kazani } \\
\text { Salas and Woodside, } 2002\end{array}$ & $\mathrm{x}$ & & & $\mathrm{x}$ & & $\mathrm{x}$ & & \\
\hline $\begin{array}{l}\text { Myrtea amorpha } \\
\text { (Sturany, 1896) }\end{array}$ & & & & $\mathrm{x}$ & & & & \\
\hline $\begin{array}{l}\text { Isorropodon perplexum } \\
\text { Sturany, } 1896\end{array}$ & $\mathrm{x}$ & $\mathrm{x}$ & & $\mathrm{x}$ & $\mathrm{x}$ & $\mathrm{x}$ & $\mathrm{x}$ & $\mathrm{x}$ \\
\hline $\begin{array}{l}\text { Taranis moerchii } \\
\text { (Malm, 1861) }\end{array}$ & $\mathrm{x}$ & & & & $\mathrm{x}$ & $\mathrm{x}$ & $\mathrm{x}$ & $\mathrm{x}$ \\
\hline Lamellibrachia sp. & & & & $\mathrm{x}$ & $\mathrm{x}$ & $\mathrm{x}$ & & \\
\hline Calliax sp. & $\mathrm{x}$ & $\mathrm{x}$ & & $\mathrm{x}$ & & $\mathrm{x}$ & $\mathrm{x}$ & $\mathrm{x}$ \\
\hline
\end{tabular}

(Ennucula corbuloides, Cardiomya costellata, Kelliella miliaris), caprellid amphipods and ghost shrimps. Numerous specimens of a callianassid ghost shrimp (Calliax sp.: Fig. 7f, Table 4) were found in the pockmark area. In the quantitative grab samples its density ranged from 1 up to 7 live animals/0.2 square metre whereas number of loose main claws ranged between 23 and 128. This is likely a still undescribed species morphologically close to an elusive callianassid taxon reported from shallower settings in the Western Mediterranean (de Gaillande and Lagardere, 1966). This species is consistently associated with such type of environments since a few specimens of this same shrimp have been 


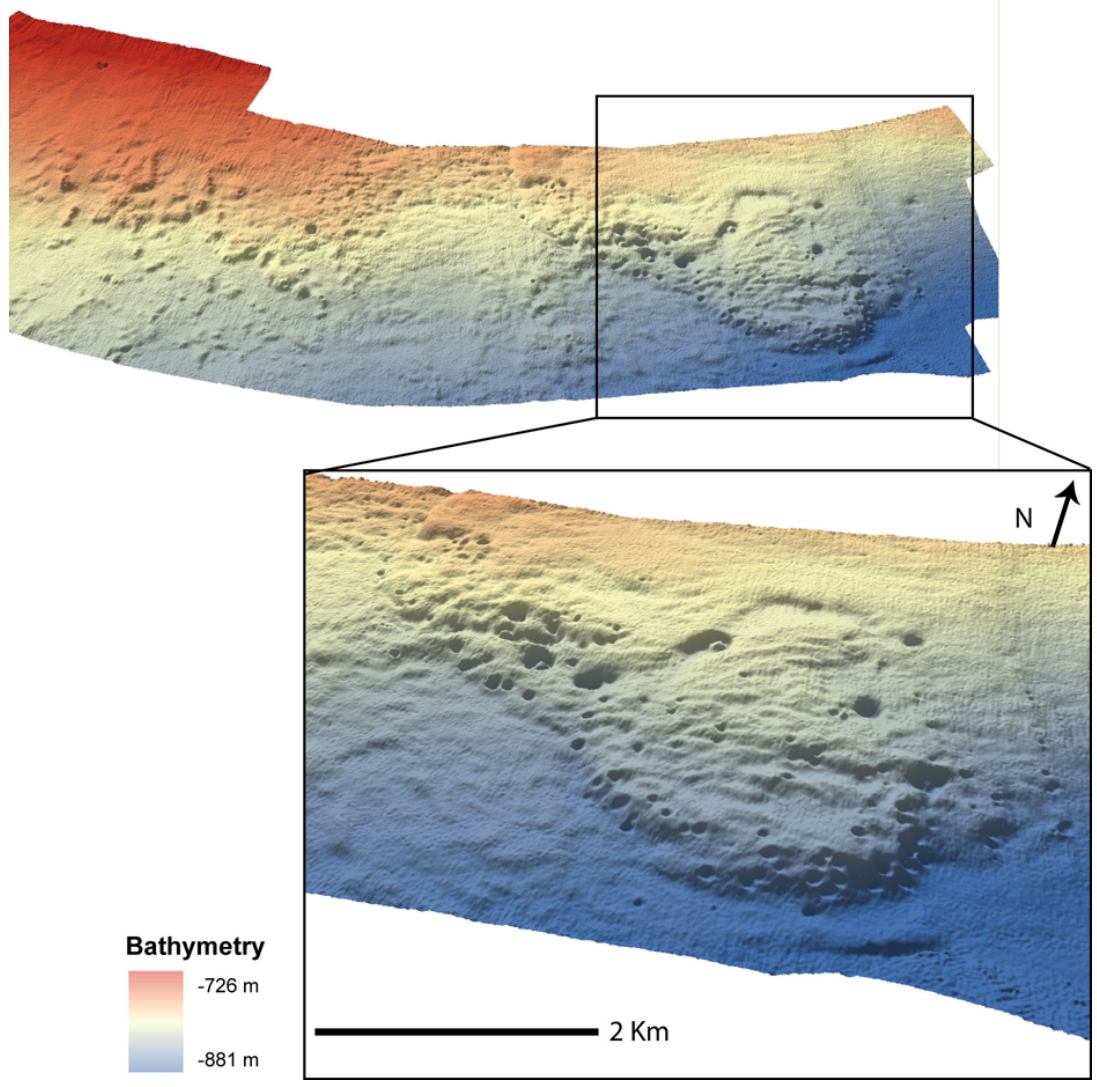

Fig. 3. Perspective view of the shaded relief DTM (resolution $5 \mathrm{~m}$ and $10 \times$ vertical exaggeration) of the study area showing the distribution of the pockmarks and their geometries; the inset shows a magnification of the highest density pockmarks area with more then 40 pockmarks with variable dimensions ( 8 of the major ones and up to 30 minor features).

also found in active pockmarks in the central Adriatic (Taviani et al., 2010). Members of the family Callianassidae are known to inhabit deep sea reducing habitats worldwide (summarised by Komai and Fujiwara, 2012). In the eastern Atlantic sector close to the Mediterranean, a new subfamily (Vulcanocalliacinae) and a new species (Vulcanocalliax arutyunovi) have been recently described by Dworschak and Cunha (2007) from a mud volcano in the deep Gulf of Cádiz.

The macrofaunal death assemblages recovered from the GBPF show a predominance of benthic molluscs over other components, predominantly decapods, pelagic molluscs, echinoids, serpulids and octocorals, Non-seep organisms are more diverse in terms of number of species (Appendix A), but chemosymbiotic bivalves in the families Lucinidae, and Vesicomyidae are at places noticeably abundant (Table 4). Lucinids are represented by the large Mediterranean endemic taxon Lucinoma kazani Salas and Woodside 2002 (Fig. 7c), and subordinately by Myrtea amorpha (Sturany, 1896) (Fig. 7e). Vesicomyidae are represented by the Mediterranean endemic Isorropodon perplexum Sturany, 1896 (Fig. 7b), the sole species recorded that far from the recent Mediterranean basin. Such bivalves have been recorded from deep sea reducing habitats in the Mediterranean basin
(Corselli and Basso, 1996; Cosel and Salas, 2001; Olu-Le Roy et al., 2004; Werne et al., 2004; Duperron et al., 2007; Duperron, 2010; Ivanov et al., 2010a, b; Ritt et al., 2010; Brissac et al., 2011; Shank et al., 2011; Taviani, 2011; Rodrigues et al., 2012).

Another remarkable megabenthic organism found in the GBPF is a siboglinid tubeworm of which only empty tubes have been collected by us (Fig. 7a). The morphology of the tube resembles Lamellibrachia, a genus recorded from deep water cold seep sites (Olu-Le Roy et al., 2004; Werne et al., 2004; Duperron et al., 2009; Ritt et al., 2010; Hilário et al., 2011; Taviani, 2011), sunken wrecks (Hughes and Crawford, 2006; Gambi et al., 2011), and hydrothermal vents (Lott and Zimmerman, 2012) in the basin. Tubes might belong to Lamellibrachia anaximandri (Southward, Andersen and Hourdea, 2011), described from the Anaximander mud volcano in the eastern Mediterranean (Southward et al., 2011), and possibly much widespread in the entire Mediterranean basin (references in Taviani, 2013). In addition to these well known deep-water chemosymbiotic metazoans, we can further list a few other taxa preferentially coping with reducing environments, i.e. thyasirid (Thyasira, Mendicula, Axinulus, Axinus) and lucinid (Myrtea spinifera) 


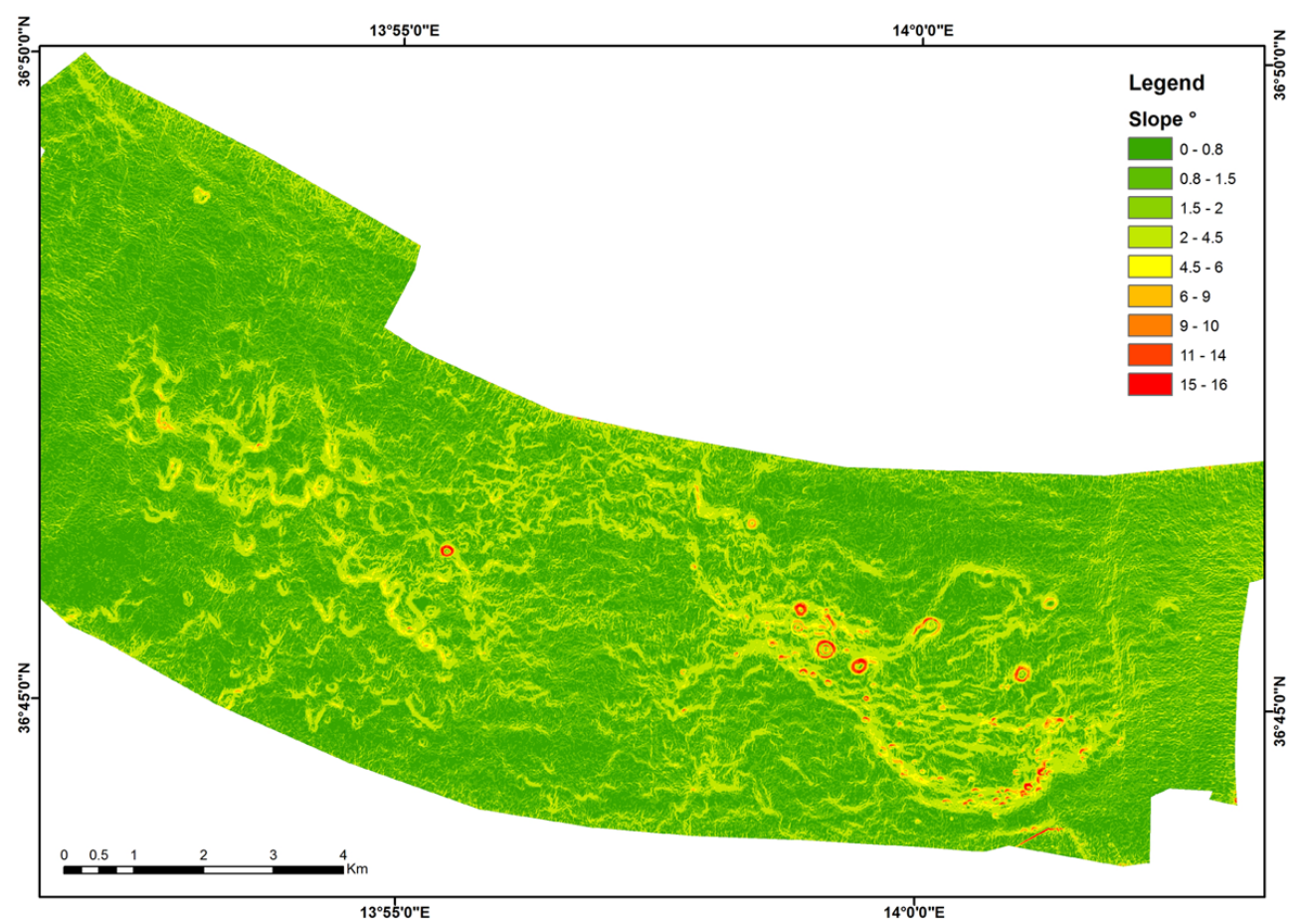

Fig. 4. Slope map of the study areas, calculated from the DTM, showing clearly the difference between the side slope of the pockmarks reaching the maximum of $16^{\circ}$ and the regional surrounding slope about $2-3^{\circ}$.

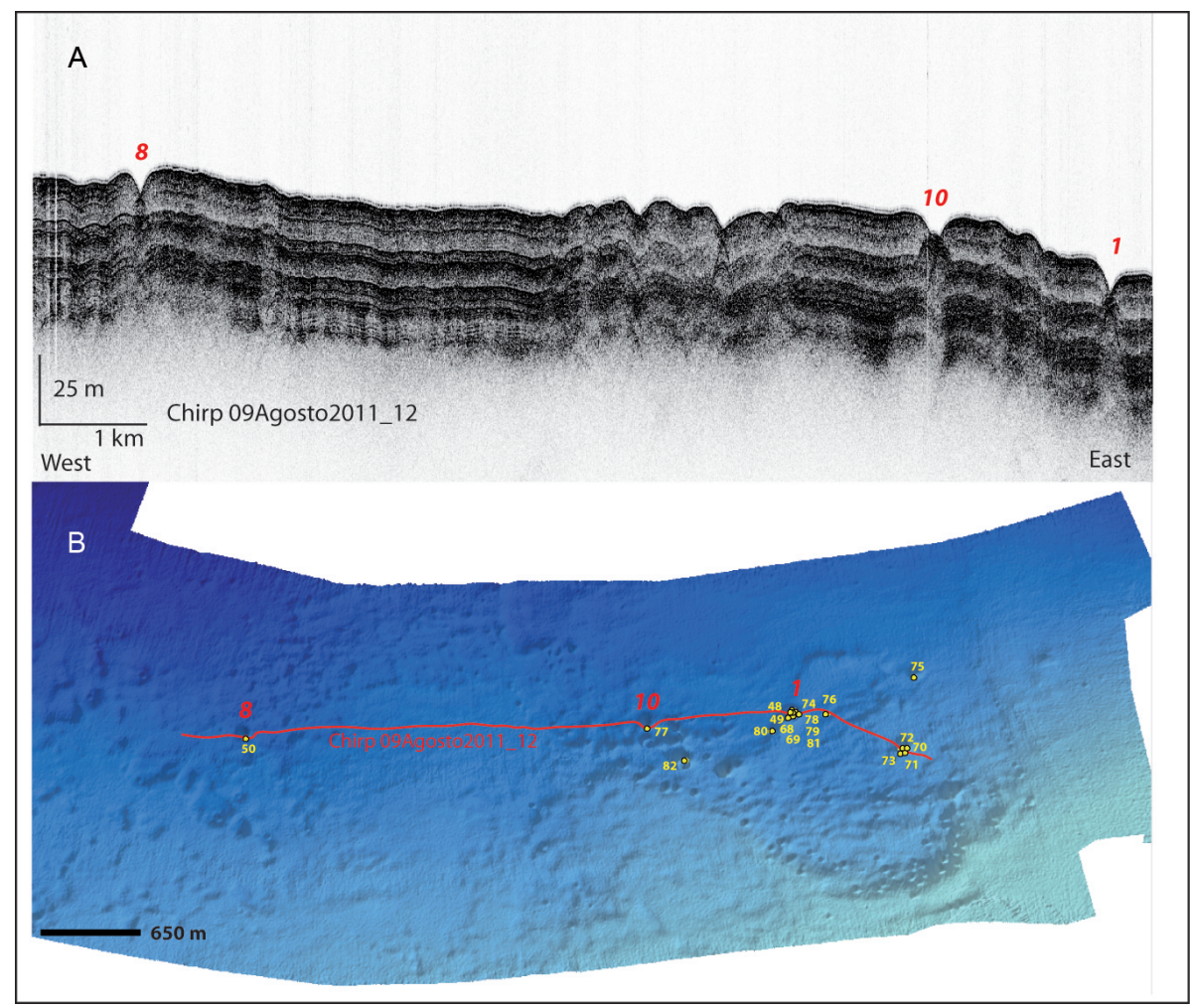

Fig. 5. (A) Chirp profile showing the subsurface stratigraphy of the pockmark area; (B) 3-D perspective view of the DTM shows the location of the chirp profile and the sample locations (yellow); red numbers are pockmarks. 

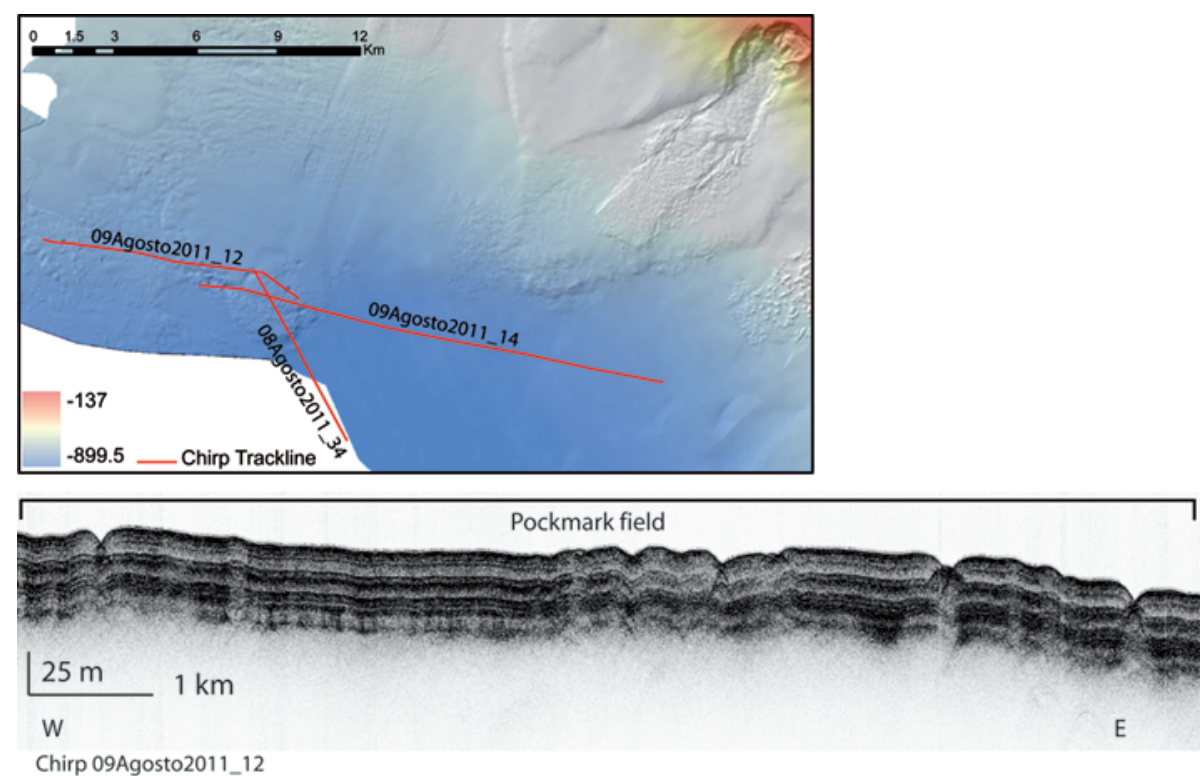

Chirp 09Agosto2011_12
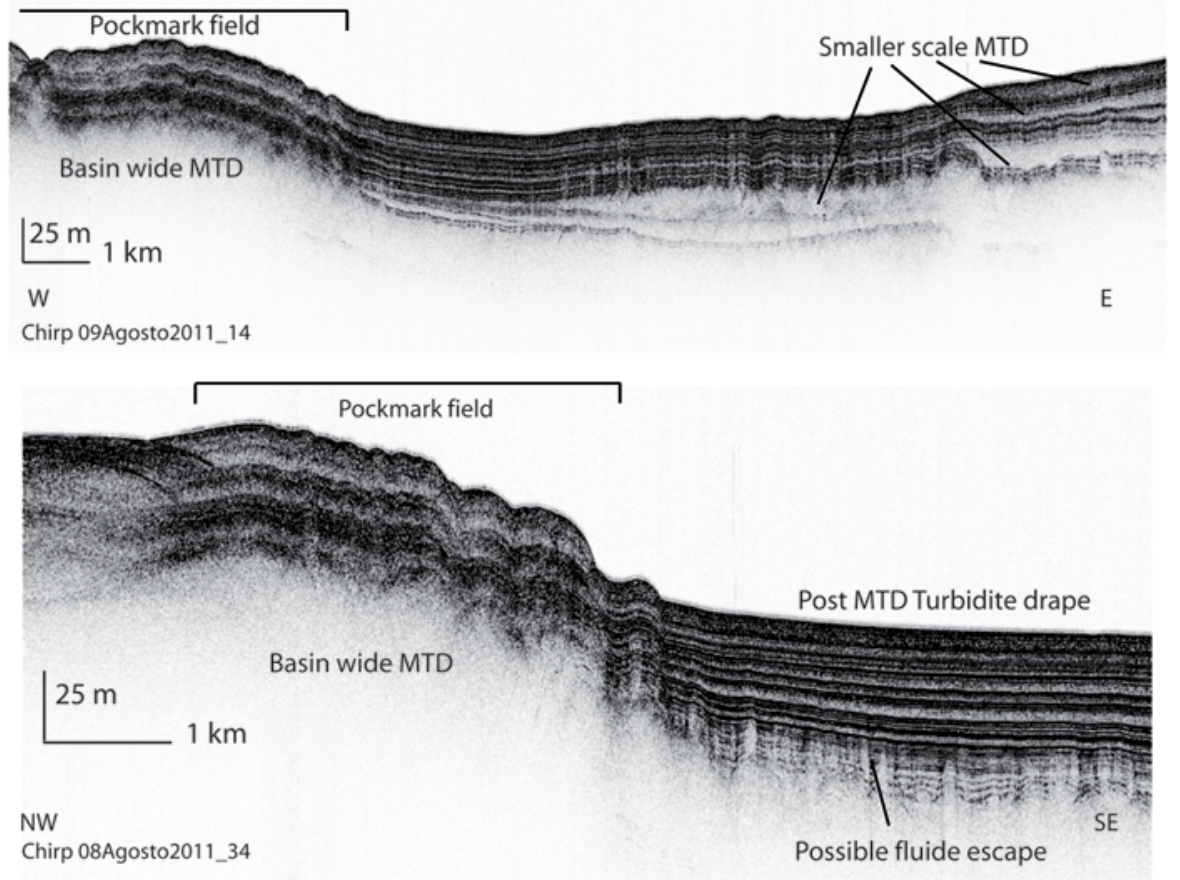

Fig. 6. Chirp sonar profiles across the pockmark-hosting morphologic bulge at the base of the slope showing the top of the last basin-wide mass-transport event (Gela slide?) and the thinning of plane-parallel reflectors (basin-plain fine-grained turbidites and hemipelagites) toward the bulge. Where thinner, this unit is likely easier to breach by the ascending fluids than in other areas.

bivalves (Dufour, 2005; Löffler et al., 2005; Taylor et al., 2007; Taylor and Glover, 2010; Brissac et al., 2011; Rodrigues and Duperron, 2011), and the turrid gastropod Taranis moerchii (Fig. 7d) that has been observed to be particularly common at such seep sites (Olu-Le Roy et al., 2004; M. Taviani, unpublished data). Only some pockmarks were found to contain spoils of truly seep communities that are instead totally absent from the sea bottom outside the pockmarks (Appendix A). Furthermore, the more emblematic cold seep species (e.g. L. kazani, I. perplexum, Lamellibrachia sp.) are not co-occurring in all investigated pockmarks in the Gela basin, showing instead a spatial variability. On the other hand, spatiotemporal variability in analogue habitats responding to variability through time and space of fluids' composition and flow intensity is a well documented trait at modern and past seepage sites (Olu et al., 1997; 

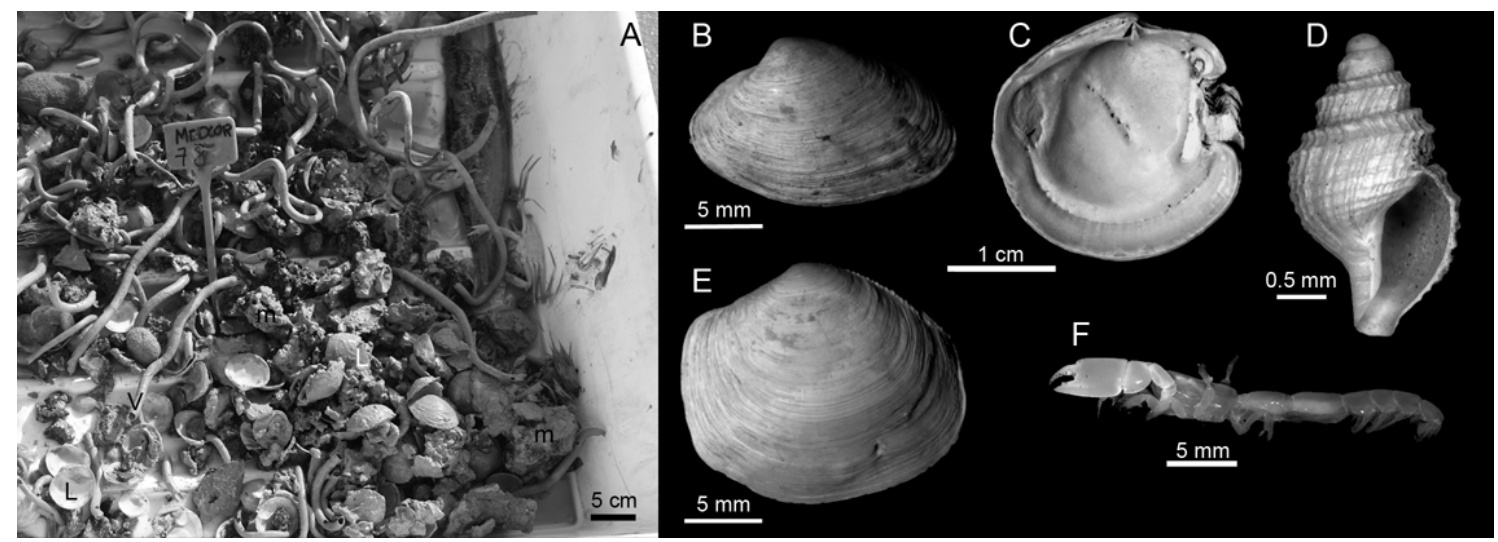

Fig. 7. Chemosymbiotic metazoans recovered from the GBPF: (A) haul whole catch of station MEDCOR 78 (pockmark \#1) showing chemosymbiotic bivalves, tubeworms, and carbonate concretions mixed with non-seep fauna and anthropogenic litter; (B) Isorropodon perplexum from st. MEDCOR71, (C) Lucinoma kazani, theratological shell from st. MEDCOR78, (D) Taranis moerchii from st. MEDCOR69, (E) Myrtea amorpha from st. MEDCOR78, (F) Calliax sp. from st. MEDCOR71.

Jenkins et al., 2007; Olu-Le Roy et al., 2007; Lessard-Pilon et al., 2010). As it is often the case, the sustainability of such chemosymbiotic bivalves and siboglinids relies upon high sulphide concentrations since their metabolic pathway is thiotrophic. Thus, they cannot be considered as direct fingerprints of hydrocarbon availability in the seeping fluids at the GBPF.

\section{Seep carbonates}

- Sediments. The pockmark field affects a predominantly silicoclastic-muddy sector of the southern Sicilian margin. Sampling however reveals the occurrence of biogenic carbonate production in the form of skeletal components shed primarily by calcified benthic organisms and subordinately by pelagics. A distinct type of carbonate biogenic sediment is produced here through cold seep factories in the form of medium to coarse skeletal assemblages enriched in shells of chemosymbiotic bivalves, mainly vesicomyids (20-40\%), and calcified parts of callianassid decapods $(30-50 \%)$ in the sand to hash fraction (Fig. 8). Secondary components in order of abundance are miliolid foraminifers (5-10\%), followed by echinoids, serpulids, ostracods and octocorals and pelagic shells. This remarkable sediment represents a novelty since its genesis is in fact related to chemical carbonate factories.

- Authigenic carbonates. Besides shells of chemosymbiotic bivalves and tubeworms, sampling from the GBPF produced also carbonate concretions, indurated burrows (Figs. 8 and 9), and cemented mudstones (Fig. 10). Microcrystalline pyrite druses were noticed on small darker carbonate concretions. Some carbonates were tested for the their stable carbon and oxygen isotopic composition (Table 2, Fig. 12). The $\delta^{13} \mathrm{C}$ composition of chemosymbiotic bivalve shells display isotopic values around between -1.23 and $+2.66 \%$ PDB reflecting the seawater carbonate reservoir as expected (Cobabe, 1998; Lietard and Pierre, 2009). The stable carbon composition of a poorly cemented layer in core MEDCOR70, provided instead a $\delta^{13} \mathrm{C}$ value of $-40.77 \%$ o PDB. A significantly carbon-depleted composition was also measured for concretioned mudstone encrusting a dead shell of the chemosymbiotic Lucinoma kazani which provided a $\delta^{13} \mathrm{C}$ value of $-37.57 \%$ PDB. Both very negative carbon signatures document unquestionably that at sometime hydrocarbons were present in the seeping fluids of this pockmark field in the Gela basin). On the other hand, this region is known to be highly productive for hydrocarbons (Etiope et al., 2002; Holland et al., 2003).

The stable carbon range is consistent with authigenic carbonates formed through the incorporation of carbon derived from anaerobic methane oxidation (Hovland et al., 1987; Roberts et al., 1987; Kulm and Suess, 1990; Aharon, 1994; Kelly et al., 1995; von Rad et al., 1996; Aloisi et al., 2000, 2002a, b; Elvert et al., 2000; Naehr et al., 2000; Greinert et al., 2001; Peckmann et al., 2001; Taviani, 2001; Gontharet et al., 2007; Campbell et al., 2008; Cangemi et al., 2010; Feng and Roberts, 2010; Ivanov et al., 2010a, b; Himmler et al., 2011; Capozzi et al., 2012). The presence of pyrite might represent a legacy of sulphate reduction in the formative environment of such carbonates (e.g. Gontharet et al., 2007). Interestingly, the GBPF concretions represent a case of incipient embedding of chemosymbiotic infaunal and epifaunal organisms in authigenic carbonates (Lalou et al., 1992), eventually turning into macrofossiliferous cold seep rocks as those diffused in the Neogene Apennine chain (Taviani, 1994, 2001, 2011). Finally, the stable oxygen composition 


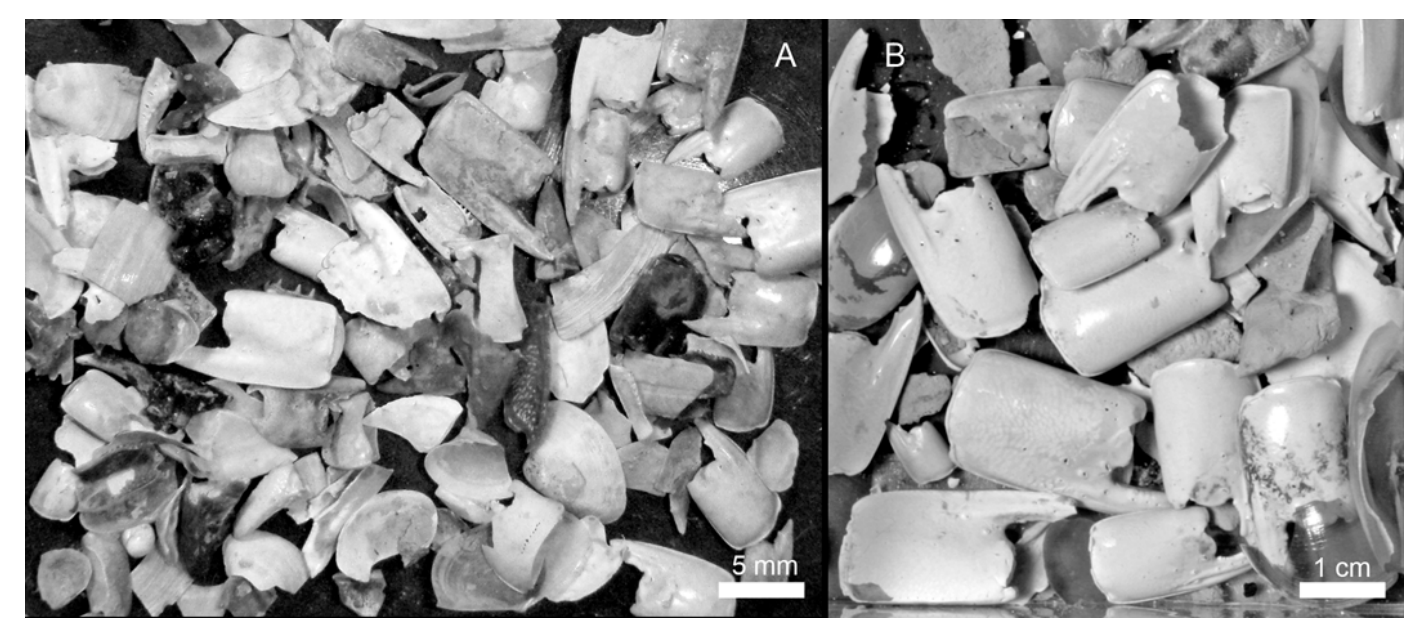

Fig. 8. Residual skeletal assemblage after washing; (A) coarse sand fraction; (B) hash fraction, all from st. MEDCOR69.

of bivalves $\left(\delta^{18} \mathrm{O}\right.$ values comprised between +2.21 and $-2.71 \%$ PDB) are interpretable as indicative of bottom cold temperatures (cf. Sakai et al., 1992), thus supporting the late glacial ages obtained by radiocarbon dating (see below).

\section{Age constraints}

The absence of distinct signals documenting either active degassing or gas charged sediment close to surface and the lack of live chemosymbiotic macro-and megafauna was taken as an indication that seepage backing the genesis of the GBPF is at present either dormant/episodic or ended. In order to unravel this fundamental aspect we examined the core record, and carbon-dated faunas and carbonate concretions. Superficial bottom samples and two sedimentary cores were taken from pockmark \#1 and \#6 (respectively MEDCOR81 and MEDCOR70) to reconstruct the recent history of fluid seepage at this place (see Fig. 11). Regarding pockmark \#1, a tube of Lamellibrachia produced an AMS- ${ }^{14} \mathrm{C}$ age of $11732 \pm 611 \mathrm{yrcal} \mathrm{BP}$, while a valve of Lucinoma kazani yielded an AMS- ${ }^{14} \mathrm{C}$ age of $9610 \pm 154 \mathrm{yrcal} \mathrm{BP}$. Isorropodon perplexum and Taranis moerchii shells from the same pockmark yielded slightly younger but roughly comparable ages of $8333 \pm 250 \mathrm{yr}$ cal BP and $8245 \pm 344 \mathrm{yrcal} \mathrm{BP}$ respectively. A valve of Myrtea amorpha from sediment core MEDCOR70 (pockmark \#6) provided an AMS- ${ }^{14} \mathrm{C}$ age of $484 \pm 54 \mathrm{yr}$ cal BP. Although potentially somewhat influenced by carbon sourced from seeping fluids, our radiocarbon ages clearly indicate that seepage activity in the pockmarks is lasting, albeit not necessarily continuatively, since the end of the last glacial epoch (Younger Dryas stadial) up to sub-recent times.

\section{Discussion}

The pockmark area investigated in this study is located at the base of the northern slope of Gela basin where Chirp-sonar profile detect the top of the last basin-wide MTD at a depth of few tens of metres under a succession of basin-floor muddy turbidites. The pockmarks area are not randomly distributed but corresponds to a bulge at the base of slope with a positive relief of few $\mathrm{km}^{2}$ (Figs. 1 and 3 ) and the overlying succession, characterised by draped and onlapping plain-parallel reflectors (muddy turbidites?) thins toward the slope and are breached by the pockmarks (Fig. 6). The perfect matching of the pockmark field with the slide-related base-of-slope bulge is suggestive of a possible causal relationship. In this view, the fluids emanating through the pockmarks would be fed from the MTD, acoustically-transparent and possibly gas charged deposit. However, in the lack of deeper-penetration MCS profiles we cannot rule out the possibility that fluids come, at least in part, from beneath the MTD rather than from it.

The genesis of the GBPF under study is thus not fully understood yet but a potential link between defluidization (pockmarks) and a main motif of this part of the continental margin (mass sediment failure) merits it to be considered. In fact, this cluster of pockmarks in the Gela basin are just located distally in front of a complex made up by stacked multiple submarine mass-transport deposits of late Pleistocene age (Minisini et al., 2007). These composite units are by large buried and only a few are exposed at present on the seabottom, the best examples of which are the "twin slides" whose multi-phase emplacement occurred since the last Post-Glacial (Minisini et al., 2007; Minisini and Trincardi, 2009). Pore fluid gradients, resulting in fluid migration and eventual expulsion onto the sea bottom, are suggested to be a potential co-driving factor, although not necessarily the dominant, in triggering episodic mass-transport 


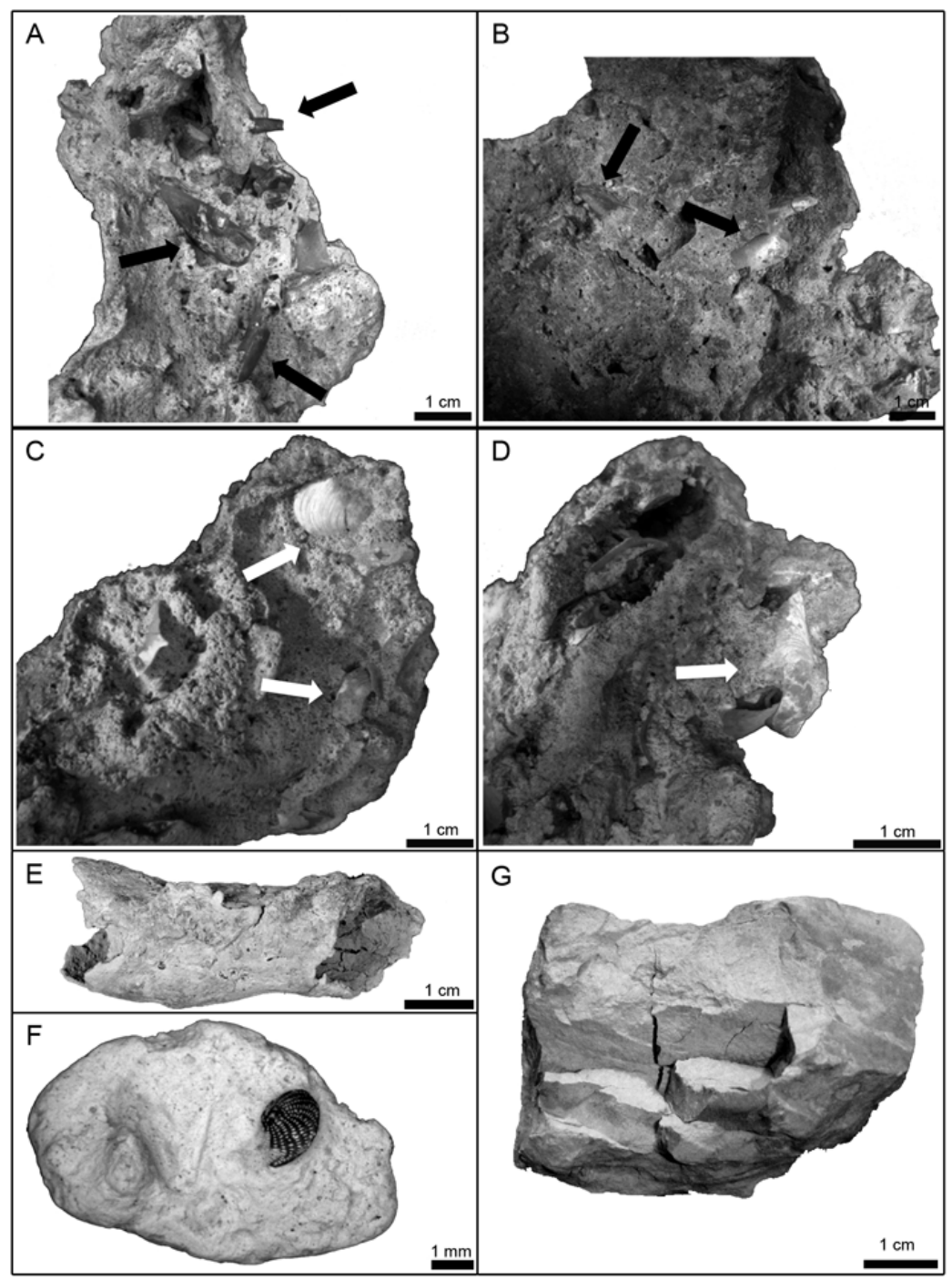

Fig. 9. Carbonates from the GBPF: (A-D) authigenic concretions (cemented matrix) embedding skeletal biosomes of seep-related metazoans, all from st. MEDCOR78: (A-B) Calliax, (C-D) Isorropodon; (E) indurated callianassid? burrow, armoured with chemosymbiotic-organisms bioclasts; (F) cemented matrix embedding a reworked black-stained shallow-water foraminifer (Elphidium crispum); (G) cemented mudstone layer at $210-230 \mathrm{~cm}$ in core MEDCOR70.

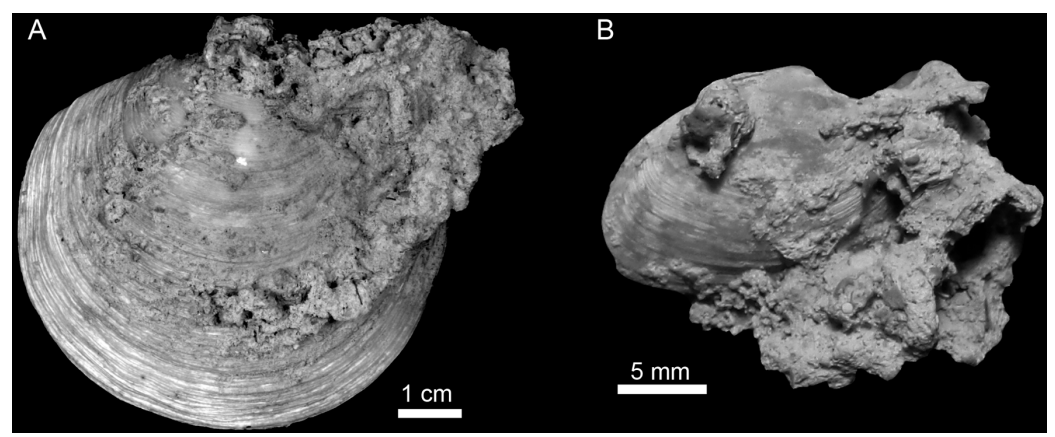

Fig. 10. Incipient methane-driven cementation of matrix on valves of chemosymbiotic bivalves from GBPF, precursors of seep-limestones: (A) Lucinoma kazani encrusted by carbon-depleted concretion $\left(\delta^{13} \mathrm{C}-37.57 \%\right.$ PDB, see text $)$, (B) Isorropodon perplexum, almost completely embedded in mudstone. 


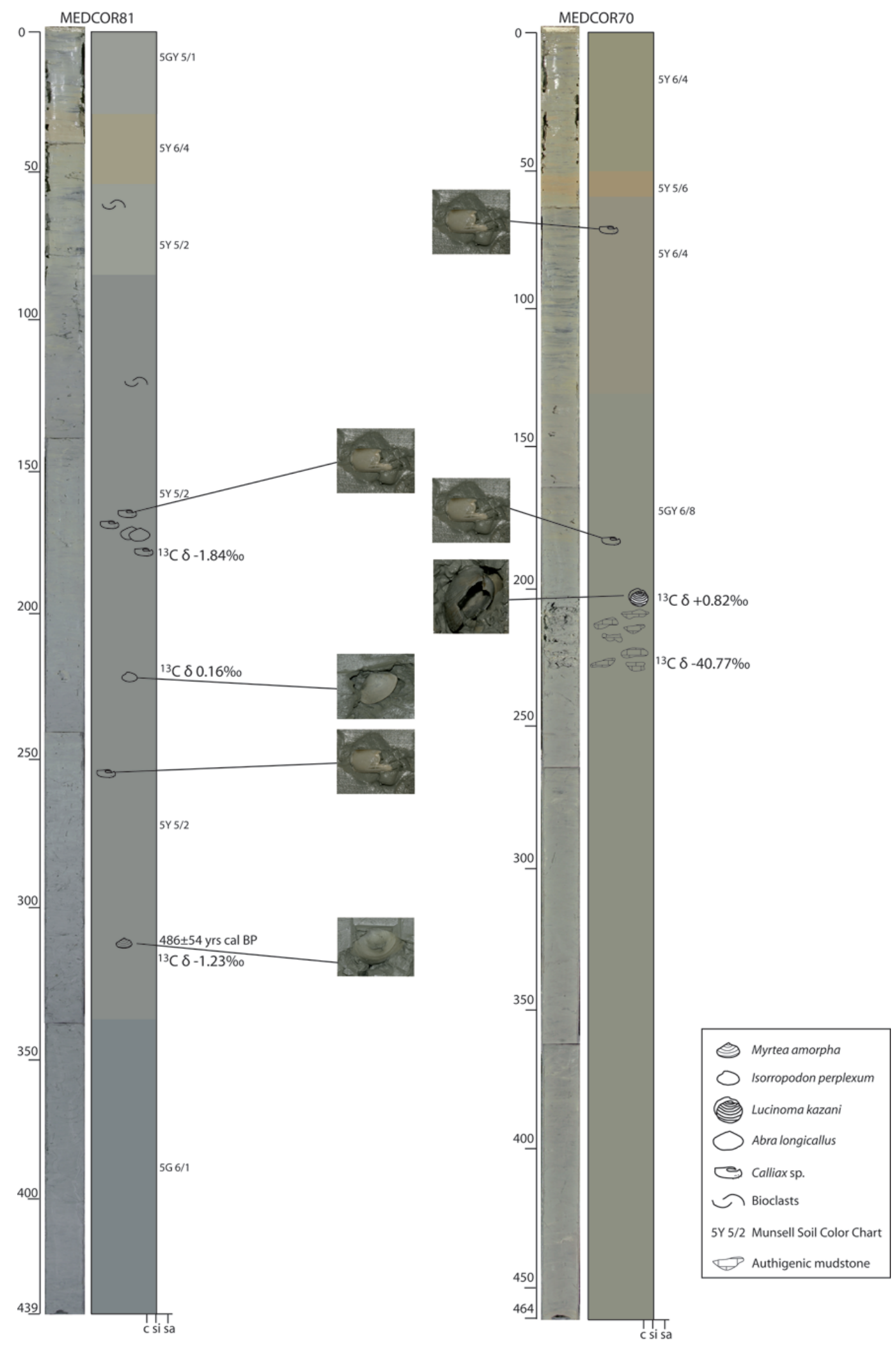

Fig. 11. Sedimentary cores MEDCOR81 (pockmark \#1), and MEDCOR70 (pockmark \#6): photographic (left) and (right) lithostratigraphic logs reporting main chronological, petrographic, isotopic and faunal features. 


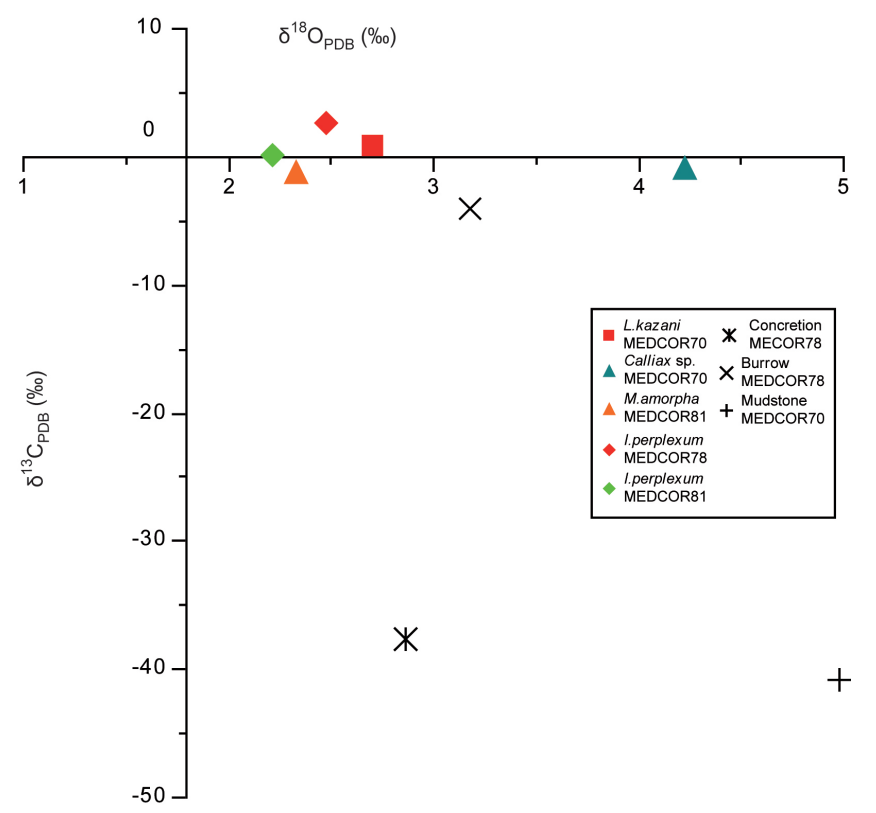

Fig. 12. Stable isotope compositions of bivalve shells (core MEDCOR 81), callianassid claw and authigenic carbonates all from st. MEDCOR70 and MEDCOR78 expressed in the conventional $\delta$ notation relative to the PDB reference standard.

events that shape this region (Minisini et al., 2007; Minisini and Trincardi, 2009). The GBPF under scrutiny here lies ca. $5 \mathrm{~nm}$ away to the west of the "twin slides" and does not appear to have contiguity with such features, suggesting that no causative link between the two phenomena (twin-slideslumping and pockmark-fluid expulsion) does exist. A series of still-unexplored pockmarks has been, however, identified at the toe of the "twin slides" (Minisini and Trincardi, 2009). It is predictable that they may in principle contain similar faunas and carbonates as their counterparts. The multiswath topographic map suggests the subsurface existence of nowdraped lobate bodies northwards of the pockmarks, that in all likeness represent buried mass-transport deposits comparable to those described by Minisini et al. (2007) from this general area. The mise-en-place process of the slumping units may in theory cause squeezing out of entrapped fluids or, otherwise, the under pressuring of fluids related to sliding off sediment that may be conducive to gas release pockmarking the bottom. Release of hydrocarbons has been invoked as a likely mechanism to trigger submarine slumps (Carpenter, 1981 and many others). On-land, similar causative scenarios have been suggested to account for localised Miocene chemosymbiotic faunal assemblages and/or authigenic carbonates associated with slumped bodies in the Apennine chain (Berti el al., 1994; Conti and Fontana, 2002; Lucente and Taviani, 2005).

The GBPF shows a certain degree of homogeneity regarding the chemosymbiotic assemblages inhabiting individual pockmarks. This is especially true for small vesi- comyids (Isorropodon), gastropods (Taranis) and callianassid decapods (Calliax) that are almost ubiquitous in our samples. Such homogeneity is not at all surprising once we consider the overall reduced variability of cold seepage at the GBPF when compared to larger and heterogenous seep sites as those observable elsewhere in the ocean (Olu et al., 1997; Sibuet and Olu-Le Roy, 2002; Olu-Le Roy et al., 2007; Cordes et al., 2010), or even in the Mediterranean itself (OluLe Roy et al., 2004). Such variability often reflects primarily variations in the fluid regimes (Teichert et al., 2003). Nevertheless, minor faunal differences are equally observable at the GBPF such as, for example, the comparable rarity of the large chemosymbiotic clam L. kazani or of the large vestimentiferan Lamellibrachia which are not recorded thus far from more than two pockmarks.

The GBPF is midway between the Eastern Mediterranean and Alboran basins where a variety of cold seep habitats is exploited by macro-and megabenthic organisms as those found in the study area (e.g., Lucinoma, Isorropodon and Lamellibrachia). Thus, it represents a relevant site to be considered in the crucial and poorly-known issue of connectivity patterns among geographically disjunct but compositionally similar deep sea chemosynthetic sites (e.g., Young, 2003; Tyler and Young, 2003; Olu-Le Roy et al., 2007; Marcus et al., 2009; Mullineaux et al., 2010).

\section{Conclusions}

1. The Gela basin deep-water pockmark field hosting Mediterranean-emblematic thiotrophic chemosymbiotic macro-and megafauna (Lucinoma, Isorropodon, Lamellibrachia) is relevant as it is the first such site in this key-region of the Mediterranean Sea transitional to its eastern and western basins;

2. the episodic occurrence of hydrocarbons in the seeping fluids is demonstrated by the occurrence of carbonate concretions and mudstones with very depleted stable carbon isotopic composition;

3. the quite different ages provided by organisms from individual pockmarks suggest that seepage activity in the area is not a uniformly-distributed and steady event but differs in space and time;

4. dating of chemosymbiotic Lamellibrachia tubeworms documents that these biota were thriving since the end of the last glacial epoch (Younger Dryas stadial) and up to very recent times;

5. a possible causative link between seepage with related pockmark genesis, and mass-transport processes is tentatively suggested but still undemonstrated. 


\section{Appendix A}

Table A1. Benthic and pelagic molluscs recovered from the GBPF during cruises MEDCOR and DECORS: taxa of proven or putative chemosymbiotic type are bold.

\begin{tabular}{|c|c|c|c|c|c|c|c|c|}
\hline & $\begin{array}{c}\text { MEDCOR } \\
69\end{array}$ & $\begin{array}{c}\text { MEDCOR } \\
71\end{array}$ & $\begin{array}{c}\text { MEDCOR } \\
76\end{array}$ & $\begin{array}{c}\text { MEDCOR } \\
78\end{array}$ & $\begin{array}{c}\text { MEDCOR } \\
80\end{array}$ & $\begin{array}{c}\text { MEDCOR } \\
82\end{array}$ & $\begin{array}{c}\text { DECORS } \\
49\end{array}$ & $\begin{array}{c}\text { DECORS } \\
50\end{array}$ \\
\hline \multicolumn{9}{|l|}{ Benthic Mollusc } \\
\hline \multicolumn{9}{|l|}{ MOLLUSCA } \\
\hline \multicolumn{9}{|l|}{ Bivalvia } \\
\hline Cardiomya costellata (Deshayes, 1833) & $\mathrm{x}$ & $\mathrm{x}$ & $\mathrm{x}$ & $\mathrm{x}$ & $\mathrm{x}$ & & $\mathrm{x}$ & $\mathrm{x}$ \\
\hline Cuspidaria rostrata (Spengler, 1793) & $\mathrm{x}$ & $\mathrm{x}$ & & $\mathrm{x}$ & & & & \\
\hline Thracia sp. & & & & $\mathrm{x}$ & & & & \\
\hline Lucinoma kazani Salas and Woodside, 2002 & $\mathbf{x}$ & & & $\mathbf{x}$ & & $\mathbf{x}$ & & \\
\hline Myrtea sp. & & & & & & & $\mathbf{x}$ & \\
\hline Myrtea amorpha (Sturany, 1896) & & & & $\mathbf{x}$ & & & & \\
\hline Myrtea spinifera (Montagu, 1803) & $\mathbf{x}$ & & & $\mathbf{x}$ & & $\mathbf{x}$ & & \\
\hline Axinulus croulinensis (Jeffreys, 1847) & & $\mathbf{x}$ & $\mathbf{x}$ & & & & & \\
\hline Axinulus eumyarius (M. Sars, 1870) & $\mathbf{x}$ & $\mathbf{x}$ & & & & & & \\
\hline Axinus grandis (Verrill and Smith [in Verrill], 1885) & $\mathbf{x}$ & $\mathbf{x}$ & $\mathbf{x}$ & & $\mathbf{x}$ & $\mathbf{x}$ & & \\
\hline Mendicula ferruginosa (Forbes, 1844) & $\mathbf{x}$ & & & & & & $\mathbf{x}$ & $\mathbf{x}$ \\
\hline Thyasira sp. & $\mathbf{x}$ & & & & & $\mathbf{x}$ & & $\mathbf{x}$ \\
\hline Thyasira succisa (Jeffreys, 1876) & & & $\mathbf{x}$ & & $\mathbf{x}$ & & $\mathbf{x}$ & \\
\hline Corbula gibba (Olivi, 1792) & & & & $\mathrm{x}$ & & $\mathrm{x}$ & & \\
\hline Xylophaga sp. & $\mathrm{x}$ & $\mathrm{x}$ & & & & & & $\mathrm{x}$ \\
\hline Acanthocardia (Gray, 1851) & & & & & & $\mathrm{x}$ & & \\
\hline Parvicardium sp. & & & $\mathrm{x}$ & & & $\mathrm{x}$ & & \\
\hline Kurtiella cf. bidentata (Montagu, 1803) & & & & & & $\mathrm{x}$ & & \\
\hline Kelliella miliaris (Philippi, 1844) & $\mathrm{x}$ & $\mathrm{x}$ & $\mathrm{x}$ & $\mathrm{x}$ & $\mathrm{x}$ & & & $\mathrm{x}$ \\
\hline Isorropodon perplexum Sturany, 1896 & $\mathbf{x}$ & $\mathbf{x}$ & & $\mathbf{x}$ & $\mathbf{x}$ & $\mathbf{x}$ & $\mathbf{x}$ & $\mathbf{x}$ \\
\hline Waisiuconcha sp. & $\mathbf{x}$ & & & & & & & \\
\hline Tellimya tenella (Lovén, 1846) & & & $\mathrm{x}$ & & & & & \\
\hline Abra longicallus (Scacchi, 1835) & $\mathrm{x}$ & $\mathrm{x}$ & $\mathrm{x}$ & $\mathrm{x}$ & $\mathrm{x}$ & $\mathrm{x}$ & $\mathrm{x}$ & $\mathrm{x}$ \\
\hline Timoclea ovata (Pennant, 1777) & & & & & & $\mathrm{x}$ & & \\
\hline Venus sp. & $\mathrm{x}$ & & & & & & & \\
\hline Bathyspinula excisa (Philippi, 1844) & & & & & & $\mathrm{x}$ & & \\
\hline Katadesmia cuneata (Jeffreys, 1876) & $\mathrm{x}$ & & & & & & & \\
\hline Malletia obtusa (G. O. Sars, 1872) & $\mathrm{x}$ & & & & & & & \\
\hline Saccella commutata (Philippi, 1844) & & & & & & $\mathrm{x}$ & & \\
\hline Microgloma sp. & & & & $\mathrm{x}$ & & & & \\
\hline Yoldiella curta Verrill and Bush, 1898 & $\mathrm{x}$ & & & & & & & \\
\hline Yoldiella lucida (Lovén, 1846) & $\mathrm{x}$ & & $\mathrm{x}$ & $\mathrm{x}$ & $\mathrm{x}$ & $\mathrm{x}$ & & \\
\hline Yoldiella nana (M. Sars, 1865) & $\mathrm{x}$ & & & & & & $\mathrm{x}$ & \\
\hline Yoldiella seguenzae Bonfitto and Sabelli, 1995 & $\mathrm{x}$ & $\mathrm{x}$ & $\mathrm{x}$ & $\mathrm{x}$ & $\mathrm{x}$ & & $\mathrm{x}$ & $\mathrm{x}$ \\
\hline Yoldia minima G. Seguenza, 1877 & & & & & & $\mathrm{x}$ & & \\
\hline Ennucula sp. & & & & & $\mathrm{x}$ & & & \\
\hline Ennucula aegeensis (Forbes, 1844) & $\mathrm{x}$ & $\mathrm{x}$ & & $\mathrm{x}$ & & & & \\
\hline Ennucula corbuloides (Seguenza, 1877) & $\mathrm{x}$ & $\mathrm{x}$ & $\mathrm{x}$ & & $\mathrm{x}$ & $\mathrm{x}$ & $\mathrm{x}$ & $\mathrm{x}$ \\
\hline Nucula sulcata Bronn, 1831 & $\mathrm{x}$ & $\mathrm{x}$ & & & & & & \\
\hline Nucula tumidula Malm, 1861 & $\mathrm{x}$ & & & $\mathrm{x}$ & & & $\mathrm{x}$ & \\
\hline Asperarca nodulosa (O. F. Müller, 1776) & & & & $\mathrm{x}$ & & & $\mathrm{x}$ & \\
\hline Bathyarca pectunculoides (Scacchi, 1835) & $\mathrm{x}$ & $\mathrm{x}$ & $\mathrm{x}$ & & $\mathrm{x}$ & & $\mathrm{x}$ & $\mathrm{x}$ \\
\hline Limatula gwyni (Sykes, 1903) & & & $\mathrm{x}$ & & & & & \\
\hline Limatula subauriculata (Montagu, 1808) & & $\mathrm{x}$ & $\mathrm{x}$ & & $\mathrm{x}$ & $\mathrm{x}$ & & \\
\hline Notolimea crassa (Forbes, 1844) & & & & & & & & \\
\hline Parvamussium sp. & & $\mathrm{x}$ & & & & & & \\
\hline Pectinidae sp. & & & & & $\mathrm{x}$ & & & \\
\hline \multicolumn{9}{|l|}{ Gastropoda } \\
\hline Bittium sp. & $\mathrm{x}$ & & & & & & & \\
\hline Turritella communis Risso, 1826 & $\mathrm{x}$ & & & $\mathrm{x}$ & & $\mathrm{x}$ & & \\
\hline Epitonium sp. & $\mathrm{x}$ & & & & & & & \\
\hline Haliella stenostoma (A. Adams, 1861) & & & & & $\mathrm{x}$ & & & \\
\hline Triphoridae sp. & $\mathrm{x}$ & & & & & & & \\
\hline Aclis attenuans Jeffreys, 1883 & & & & & & $\mathrm{x}$ & & \\
\hline Melanella sp. & & $\mathrm{x}$ & & & & & & \\
\hline Naticidae sp. & $\mathrm{x}$ & & & & $\mathrm{x}$ & & & \\
\hline Euspira fusca (Blainville, 1825) & & & & $\mathrm{x}$ & & & & \\
\hline Alvania sp.1 & & & $\mathrm{x}$ & & & & & \\
\hline Alvania sp. 2 & & & & & & $\mathrm{x}$ & & \\
\hline Alvania cimicoides (Forbes, 1844) & $\mathrm{x}$ & $\mathrm{x}$ & $\mathrm{x}$ & $\mathrm{x}$ & $\mathrm{x}$ & $\mathrm{x}$ & $\mathrm{x}$ & \\
\hline Alvania elegantissima (Monterosato, 1875) & $\mathrm{x}$ & $\mathrm{x}$ & & $\mathrm{x}$ & & $\mathrm{x}$ & & \\
\hline Alvania subsoluta (Aradas, 1847) & $\mathrm{x}$ & $\mathrm{x}$ & $\mathrm{x}$ & & $\mathrm{x}$ & $\mathrm{x}$ & $\mathrm{x}$ & $\mathrm{x}$ \\
\hline Alvania testae (Aradas and Maggiore, 1844) & & & $\mathrm{x}$ & & & & & \\
\hline
\end{tabular}


Table A1. Continued.

\begin{tabular}{|c|c|c|c|c|c|c|c|c|}
\hline & $\begin{array}{c}\text { MEDCOR } \\
69\end{array}$ & $\begin{array}{c}\text { MEDCOR } \\
71\end{array}$ & $\begin{array}{c}\text { MEDCOR } \\
76\end{array}$ & $\begin{array}{c}\text { MEDCOR } \\
78\end{array}$ & $\begin{array}{c}\text { MEDCOR } \\
80\end{array}$ & $\begin{array}{c}\text { MEDCOR } \\
82\end{array}$ & $\begin{array}{c}\text { DECORS } \\
49\end{array}$ & $\begin{array}{c}\text { DECORS } \\
50\end{array}$ \\
\hline Benthonella tenella (Jeffreys, 1869) & $\mathrm{x}$ & $\mathrm{x}$ & $\mathrm{x}$ & $\mathrm{x}$ & $\mathrm{x}$ & $\mathrm{x}$ & $\mathrm{x}$ & $\mathrm{x}$ \\
\hline Aporrhais serresianus (Michaud, 1828) & & $\mathrm{x}$ & & & & & & $\mathrm{x}$ \\
\hline Galeodea echinophora (Linnaeus, 1758) & & & & & $\mathrm{x}$ & & & \\
\hline Amphissa acutecostata (Philippi, 1844) & $\mathrm{x}$ & & & $\mathrm{x}$ & & $\mathrm{x}$ & & \\
\hline \multicolumn{9}{|l|}{ Fusinus rostratus (Olivi, 1792) } \\
\hline Drilliola emendata (Monterosato, 1872) & & & & $\mathrm{x}$ & & & & \\
\hline Drilliola loprestiana (Calcara, 1841) & $\mathrm{x}$ & $\mathrm{x}$ & & & & & & \\
\hline Spirotropis modiolus (de Cristofori and Jan, 1832) & & $\mathrm{x}$ & & & & & & \\
\hline Mangelia serga (Dall, 1881) & & $\mathrm{x}$ & & & $\mathrm{x}$ & & & \\
\hline Pleurotomella gibbera Bouchet and Warén, 1980 & & $\mathrm{x}$ & $\mathrm{x}$ & & $\mathrm{x}$ & & $\mathrm{x}$ & $\mathrm{x}$ \\
\hline Taranis moerchii (Malm, 1861) & $\mathbf{x}$ & & & & $\mathbf{x}$ & $\mathbf{x}$ & $\mathbf{x}$ & $\mathbf{x}$ \\
\hline Teretia teres (Reeve, 1844$)$ & & $\mathrm{x}$ & & & & & & \\
\hline Granulina gofasi Smriglio \& Mariottini, 1996 & & & & $\mathrm{x}$ & $\mathrm{x}$ & & & \\
\hline Pagodula echinata (Kiener, 1840) & $\mathrm{x}$ & $\mathrm{x}$ & $\mathrm{x}$ & $\mathrm{x}$ & $\mathrm{x}$ & $\mathrm{x}$ & $\mathrm{x}$ & \\
\hline Trophonopsis barvicensis (Johnston, 1825) & $\mathrm{x}$ & $\mathrm{x}$ & & & $\mathrm{x}$ & & & \\
\hline Bathysciadium xylophagum Warén and Carrozza in Warén, 1997 & $\mathrm{x}$ & $\mathrm{x}$ & & & & & & \\
\hline Acteon pusillus (Forbes, 1844) & & & $\mathrm{x}$ & & & & & \\
\hline Crenilabium exile (Jeffreys, 1870) & $\mathrm{x}$ & & $\mathrm{x}$ & & $\mathrm{x}$ & $\mathrm{x}$ & & \\
\hline Eulimella sp. & & & & & $\mathrm{x}$ & & & \\
\hline Syrnola sp. & & & & & $\mathrm{x}$ & & & \\
\hline Colpodaspis sp. & & & $\mathrm{x}$ & & & & & \\
\hline Diaphana lactea (Jeffreys, 1877) & & $\mathrm{x}$ & & & $\mathrm{x}$ & & $\mathrm{x}$ & \\
\hline Philine sp. & & & & & $\mathrm{x}$ & & & \\
\hline Philine scabra (Müller, 1784) & & & & & $\mathrm{x}$ & & & \\
\hline Philine monterosatoi (Sykes, 1905) & $\mathrm{x}$ & & & & & & $\mathrm{x}$ & \\
\hline Roxania monterosatoi Dautzenberg and H. Fischer, 1896 & $\mathrm{x}$ & $\mathrm{x}$ & & & & & $\mathrm{x}$ & $\mathrm{x}$ \\
\hline Fissurisepta granulosa Jeffreys, 1883 & & & & & & $\mathrm{x}$ & & \\
\hline Putzeysia wiseri (Calcara, 1842) & & & & $\mathrm{x}$ & & $\mathrm{x}$ & & \\
\hline Dikoleps sp. & & & & & $\mathrm{x}$ & & & \\
\hline \multicolumn{9}{|l|}{ Polyplacophora } \\
\hline Hanleya sp. & & & & & & $\mathrm{x}$ & & \\
\hline \multicolumn{9}{|l|}{ Scaphopoda } \\
\hline Antalis agilis (M. Sars in G.O. Sars, 1872) & & $\mathrm{x}$ & $\mathrm{x}$ & $\mathrm{x}$ & $\mathrm{x}$ & & & $\mathrm{x}$ \\
\hline Dentalium sp. & & & & & & $\mathrm{x}$ & & \\
\hline Entalina tetragona $($ Brocchi, 1814) & $\mathrm{x}$ & & & & & $\mathrm{x}$ & & \\
\hline \multicolumn{9}{|l|}{ Pelagic Mollusc } \\
\hline \multicolumn{9}{|l|}{ Caenogastropoda } \\
\hline Janthina sp. & & & & & $\mathrm{x}$ & & & \\
\hline Carinaria lamarckii Blainville, 1817 & & $\mathrm{x}$ & & & & & & \\
\hline Atlanta brunnea J. E. Gray, 1850 & $\mathrm{x}$ & $\mathrm{x}$ & & & $\mathrm{x}$ & & & \\
\hline Atlanta peronii Lesueur, 1817 & $\mathrm{x}$ & $\mathrm{x}$ & $\mathrm{x}$ & $\mathrm{x}$ & $\mathrm{x}$ & $\mathrm{x}$ & $\mathrm{x}$ & $\mathrm{x}$ \\
\hline \multicolumn{9}{|l|}{ Heterobranchia } \\
\hline Cavolinia inflexa (Lesueur, 1813) & & $\mathrm{x}$ & & $\mathrm{x}$ & & $\mathrm{x}$ & $\mathrm{x}$ & $\mathrm{x}$ \\
\hline Cavolinia tridentata (Forsskål in Niebhur, 1775) & $\mathrm{x}$ & $\mathrm{x}$ & $\mathrm{x}$ & $\mathrm{x}$ & & & $\mathrm{x}$ & $\mathrm{x}$ \\
\hline Cavolinia uncinata (Rang, 1829) & $\mathrm{x}$ & $\mathrm{x}$ & & $\mathrm{x}$ & $\mathrm{x}$ & & $\mathrm{x}$ & \\
\hline Diacria trispinosa (Blainville, 1821) & $\mathrm{x}$ & $\mathrm{x}$ & & $\mathrm{x}$ & $\mathrm{x}$ & & & \\
\hline Clio pyramidata Linnaeus, 1767 & $\mathrm{x}$ & $\mathrm{x}$ & & $\mathrm{x}$ & $\mathrm{x}$ & $\mathrm{x}$ & & \\
\hline Creseis clava (Rang, 1828) & $\mathrm{x}$ & $\mathrm{x}$ & & $\mathrm{x}$ & $\mathrm{x}$ & $\mathrm{x}$ & & \\
\hline Hyalocylis striata (Rang, 1828) & $\mathrm{x}$ & $\mathrm{x}$ & $\mathrm{x}$ & & $\mathrm{x}$ & & & \\
\hline Styliola subula (Quoy and Gaimard, 1827) & $\mathrm{x}$ & $\mathrm{x}$ & $\mathrm{x}$ & $\mathrm{x}$ & $\mathrm{x}$ & $\mathrm{x}$ & $\mathrm{x}$ & $\mathrm{x}$ \\
\hline Heliconoides inflatus (d'Orbigny, 1834) & & $\mathrm{x}$ & & $\mathrm{x}$ & $\mathrm{x}$ & & $\mathrm{x}$ & $\mathrm{x}$ \\
\hline Limacina sp. & & & & & & $\mathrm{x}$ & & $\mathrm{x}$ \\
\hline Limacina bulimoides (d'Orbigny, 1834) & $\mathrm{x}$ & & & & $\mathrm{x}$ & & & \\
\hline Limacina trochiformis (d'Orbigny, 1834) & $\mathrm{x}$ & $\mathrm{x}$ & & & $\mathrm{x}$ & & & \\
\hline Peracle diversa (Monterosato, 1875) & $\mathrm{x}$ & $\mathrm{x}$ & $\mathrm{x}$ & & $\mathrm{x}$ & & & $\mathrm{x}$ \\
\hline Peracle reticulata (d'Orbigny, 1834) & $\mathrm{x}$ & & $\mathrm{x}$ & & $\mathrm{x}$ & & & \\
\hline
\end{tabular}

Acknowledgements. We are indebted to officers, crew, and colleagues for their skilful cooperation during the HERMES05, MEDCOR and DECORS Cruises supported by the FPVI Integrated Projects HERMES (GOCE-CT-2005-511234-1) HERMIONE (grant agreement no: 226354). The article is also a contribution to the FP-VII-7 COCONET (Grant agreement no: 287844) of the European Community, and to the national projects PRIN "Carbonate conduits linked to hydrocarbons enriched seepages" and RITMARE (Ricerca italiana per mare) both funded by the Italian Ministry of Research and Technology (MIUR). We are grateful to two anonymous referees for their useful comments. This is ISMAR-CNR scientific contribution no. 1778.

Edited by: R. Danovaro 


\section{References}

Aharon, P.: Geology and biology of modern and ancient submarine hydrocarbon seeps and vents, Geo-Mar. Lett., 14, 69-230, 1994.

Aloisi, G., Pierre, C., Rouchy, J.-M., Foucher, J.-P., and Woodside, J.: Methane-related authigenic carbonates of eastern Mediterranean Sea mud volcanoes and their possible relation to gas hydrate destabilisation, Earth Planet. Sc. Lett., 184, 321-338, 2000.

Aloisi, G., Bouloubassi, L., Heijs, S. K., Pancost, R., Pierre, C., Sinnighe Damsté, J. S., Gottschal, J. C., Forney, L. J., and Rouchy, J.-M.: $\mathrm{CH}^{4}$-consuming microorganisms and the formation of carbonate crusts at cold seeps, Earth Planet. Sc. Lett., 203, 195-203, 2002a.

Aloisi, G., Pierre, C., Rouchy, J.-M., and Faugres, J.-C.: Isotopic evidence of methane-related diagenesis in the mud volcanic sediments of the Barbados Accretionary Prism, Cont. Shelf Res., 22, 2355-2372, 2002b.

Berti, M., Cuzzani, M. G., Landuzzi, A., Taviani, M., Aharon, P., and Vai, G. B.: Hydrocarbon derived imprints in olistostromes of the Early Serravallian Marnoso-arenacea Formation, Romagna Apennines (Northern Italy), Geo-Mar. Lett., 14, 192-200, 1994.

Brissac, T., Rodrigues, C. F., Gros, O., and Duperron, S.: Characterization of bacterial symbioses in Myrtea sp. (Bivalvia: Lucinidae) and Thyasira sp. (Bivalvia: Thyasiridae) from a cold seep in the Eastern Mediterranean, Mar. Ecol., 32, 198-210, 2011.

Campbell, K. A., Francis, D. A., Collins, M., Gregory, M. R., Nelson, C. S., Greinert, J., and Aharon, P.: Hydrocarbon seepcarbonates of a Miocene forearc (East Coast Basin), North Island, New Zealand, Sediment. Geol., 204, 83-105, 2008.

Cangemi, M., Di Leonardo, R., Bellanca, A., Cundy, A., Neri, R., and Angelone, M.: Geochemistry and mineralogy of sediments and authigenic carbonates from the Malta Plateau, Strait of Sicily (Central Mediterranean): Relationships with mud/fluid release from a mud volcano system, Chem. Geol., 276, 294-308, 2010.

Capozzi, R., Guido, F. L., Oppo, D., and Gabbianelli, G.: Methanederived authigenic carbonates (MDAC) in northern-central Adriatic Sea: Relationships between reservoir and methane seepages, Mar. Geol., 332-334, 174-188, 2012.

Carpenter, G.: Coincident sediment slump/clathrate complexes on the U.S. Atlantic continental slope, Geo-Mar. Lett., 1, 29-32, 1981.

Cavanaugh, C. M., McKiness, Z. P., and Newton, I. L. G.: Marine Chemosynthetic Symbioses, in: The Prokaryotes, 3 Edn., A Handbook on the biology of Bacteria: Symbiotic associations, Biotechnology, Applied Microbiology, edited by: Dworkin, M., Falkow, S., Rosenberg, E., Schleifer, K. H., and Stackebrandt, E., Springer New York, 473-508, 2006.

Cobabe, E. A.: Chemosynthesis and chemosymbiosis in the fossil record: detecting unusual communities using isotope geochemistry, in: Isotope paleobiology and paleoecology, edited by: Norris, R. D. and Corfield, R. M., The Paleontological Society Papers, 4, 255-285, 1998.

Coleman, D. F., Austin, J. A., Ben-Avraham, Z., Makowsky, Y., and Tchernov, D.: Seafloor pockmarks, deepwater corals, and cold seeps along the continental margin of Israel, Oceanography, Suppl., 25, 40-41, 2012.

Conti, S. and Fontana, D.: Sediment instability related to fluid venting in Miocene authigenic carbonate deposits of the northern Apennines (Italy), Int. J. Earth Sci., 91, 1030-1040, 2002.
Cordes, E. E., Becker, E. L., Hourdez, S., and Fisher, C. R.: Influence of foundation species, depth, and location on diversity and community composition at Gulf of Mexico lower-slope cold seeps, Deep-Sea Res. Pt. II, 57, 1870-1881, 2010.

Corselli, C. and Basso, D.: First evidence of benthic communities based on chemosynthesis on the Napoli mud volcano (Eastern Mediterranean), Mar. Geol., 132, 227-239, 1996.

Cosel, R. and Salas, C.: Vesicomyidae (Mollusca: Bivalvia) of the genera Vesicomya, Waisiuconcha, Isorropodon and Callogonia in the eastern Atlantic and the Mediterranean, Sarsia, 86, 333-366, 2001.

Curzi, P. V.: Central Adriatic geology and fishing, Aracne Editrice Bologna, 274 pp., 2012.

Curzi, P. V. and Veggiani, A.: I Pockmarks nel mare Adriatico centrale, Acta Naturalia de "L'Ateneo Parmense", 21, 79-90, 1985.

Curzi, P. V., Canu, M., Casini Ropa, D., and Rossi, S.: Geoengineering Hazard study in the Adriatic sea, Offshore Mar. Engin., 2, 5-15, 1988.

Dando, P. R.: A review of pockmarks in the UK part of the North Sea, with particular respect to their biology, Strategic Environmental Assessment - SEA2 Technical Report TR 001, 21 pp., 2001.

De Gaillande, D. and Lagardère, J.-P.: Description de Callianassa (Callichirus) lobata nov. sp. (Crustacea Decapoda Callianassidae), Recueil des Travaux de la Station Marine d'Endoume, 40, 259-265, 1966.

Dufour, S. C.: Gill anatomy and the evolution of symbiosis in the bivalve family Thyasiridae, Biol. Bull., 208, 200-212, 2005.

Duperron, S.: The diversity of deep-sea mussels and their bacterial symbioses, in: The Vent and Seep Biota, Topics in Geobiology, edited by: Kiel, S., 33, Springer Science + Business Media BV, 137-167, 2010.

Duperron, S., Fiala-Médioni, A., Caprais, J.-C., Olu, K., and Sibuet, M.: Evidence for chemoautotrophic symbiosis in a Mediterranean cold seep clam (Bivalvia: Lucinidae): comparative sequence analysis of bacterial 16S rRNA, APS, reductase and rubisCO genes, FEMS Microbiol. Ecol., 59, 64-70, 2007.

Duperron, S., de Beer, D., Zbinden, M., Boetius, A., Schipani, V., Kahil, N., and Gaill, F.: Molecular characterisation of bacteria associated with the trophosome and the tube of Lamellibrachia sp., a siboglinid annelid from cold seeps in the eastern Mediterranean, FEMS Microbiol. Ecol., 69, 395-409, 2009.

Dworschak, P. C. and Cunha, M.,: A new subfamily, Vulcanocalliacinae n. subfam., for Vulcanocalliax arutyunovi n. gen., n. sp. from a mud volcano in the Gulf of Cádiz (Crustacea, Decapoda, Callianassidae), Zootaxa, 1460, 35-46, 2007.

Elvert, M., Suess, E., Greinert, J., and Whiticar, M. J.: Archaea mediating anaerobic oxidation in deep-sea sediments at cold seeps of the eastern Aleutian subduction zone, Organic Geochem., 31, 1175-1187, 2000

Etiope, G., Caracausi, A., Favara, R., Italiano, F., and Baciu, C.: Methane emission from the mud volcanoes of Sicily (Italy), Geophys. Res. Lett., 29, doi:10.1029/2001GL014340, 2002.

Feng, D. and Roberts, H. H.: Initial results of comparing cold-seep carbonates from mussel and tubeworm-associated environments at Atwater Valley lease block 340, northern Gulf of Mexico, Deep-Sea Res. Pt. II, 57, 2030-2039, 2010.

Gambi, M. C., Schulze, A., and Amato, E.: Record of Lamellibrachia sp. (Annelida: Siboglinidae: Vestimentifera) from a deep 
shipwreck in the western Mediterranean Sea (Italy), Mar. Biodivers. Rec., 4, 1-6, 2011.

Gay, A., Lopez, M., Cochonat, P., Sultan, N., Cauquil, E., and Brigaud, F.: Sinuous pockmarks belt as indicator of 5 a shallow buried turbiditic channel on the lower slope of the Congo Basin, West African Margin, Geological Society London Special Publication, 216, 173-189, 2003.

Geletti, R., Del Ben, A., Busetti, M., Ramella, R., and Volpi, V.: Gas Seeps linked to salt structures in the Central Adriatic Sea, Basin Res., 20, 473-487, 2008.

Gontharet, S., Pierre, C., Blanc-Valleron, M.-M., Rouchy, J. M., Fouquet, Y., Bayon, G., Foucher, J. P., Woodside, J., and Mascle, J.: The Nautinil Scientific Party: Nature and origin of diagenetic carbonate crusts and concretions from mud volcanoes and pockmarks of the Nile deep-sea fan (eastern Mediterranean Sea), Deep-Sea Res. Pt. II, 54, 1292-1311, 2007.

Greinert, J., Gerhard, B., and Suess, E.: Gas hydrate-associated carbonates and methane venting at hydrate ridge: Classification, distribution, and origin of authigenic lithologies, in: Natural gas hydrates: Occurrence, distribution, and detection edited by: Paull, C. K, and Dillon, W. P., American Geophysical Union Geophysical Monograph, 124, 99-113, 2001.

Hilário, A., Comas, M. C., Azevedo, L., Pinheiro, L., Ivanov, M. K., and Cunha, M. R.: First record of a Vestimentifera (Polychaeta: Siboglinidae) from chemosynthetic habitats in the western Mediterranean Sea - Biogeographical implications and future exploration, Deep-Sea Res. Pt. I, 58, 200-207, 2011.

Himmler, T., Brinkmann, F., Bohrmann, G., and Peckmann, J.: Corrosion patterns of seep carbonates from the eastern Mediterranean Sea, Terra Nova, 23, 206-212, 2011.

Holland, C. W., Etiope, G., Milkov, A. V., Michelozzi, E., and Favali, P.: Mud volcanoes discovered offshore Sicily, Mar. Geol., 199, 1-6, 2003.

Hovland, M.: The formation of pockmarks and their potential influence on offshore construction, Proc. JSCE, 388/III-8, Geotechnical Engineering, 13-22, 1987.

Hovland, M.: The formation of pockmarks and their potential influence on offshore construction, Q. J. Eng. Geol., 22, 131-138, 1989.

Hovland, M.: Hydrocarbon seeps in northern marine waters - their occurrence and effects, Palaios, 7, 376-382, 1992.

Hovland, M. and Curzi, P.: Gas seepage and assumed mud diapirism in the Italian central Adriatic Sea, Mar. Petrol. Geol., 6, 161-169, 1989.

Hovland, M. and Judd, A. G.: Seabed Pockmarks and Seepages, Graham \& Trotman, London, 293 pp., 1988.

Hovland, M. and Thomsen, E.: Hydrocarbon-based communities in the North Sea?, Sarsia, 74, 29-40, 1989.

Hovland, M., Talbot, M. R., Qvale, H., Olaussen, S., and Aasberg, L.: Methane-derived carbonate cements in pockmarks of the North Sea, J. Sediment. Petrol., 57, 881-892, 1987.

Hughes, D. J. and Crawford, M.: A new record of the vestimentiferan Lamellibrachia sp. (Polychaeta: Siboglinidae) from a deep shipwreck in the eastern Mediterranean, Mar. Biodivers. Rec., 1, 1-3, 2006.

Ivanov, M. K., Kenyon, N. H., Laberg, J.-S., and Blinova, V. N.: Cold seeps, coral Mounds and deep-water depositional systems of the Alboran Sea, Gulf of Cadiz and Norwegian continental margin, Preliminary results of investigations during the TTR-17 cruise of RV Professor Logachev, June-July 2008, IOC Techn. Ser., 94, 2010a.

Ivanov, M. K., Mazzini, A., Blinova, V. N., Kozlova, E., Laberg, J.-S., Matveeva, T., Taviani, M., and Kaskov, N.: Seep mounds on the southern Vøring Plateau (offshore Norway), Mar. Petrol. Geol., 27, 1235-1261, 2010b.

Jenkins, R. G., Kaim, A., Hikika, Y., and Tanabe, K.: Methaneflux-dependent lateral faunal changes in a Late Cretaceous chemosymbiontic assemblage from the Nakagawa area of Hokkaido, Japan, Geobiology, 5, 127-139, 2007.

Kelley, J. T., Dickson, S. M., Belknap, D. F., Barnhardt, W. A., and Henderson, M.: Giant sea-bed pockmarks: evidence for gas escape from Belfast Bay, Maine, Geology, 22, 59-63, 1994.

Kelly, S. R. A., Ditchfield, P. W., Doubleday, P. A., and Marshall, J. D.: An Upper Jurassic methane-seep limestone from the fossil Bluff Group forearc basin of Alexander Island, Antarctica, J. Sediment. Res., A65, 274-282, 1995.

King, L. H. and Maclean, B.: Pockmarks on the Scotian Shelf, Geol. Soc. Am. Bull., 81, 3141-3148, 1970.

Komai, T. and Fujiwara, Y.: New records of callianassid ghost shrimp (Crustacea: Decapoda: Axiidea) from reducing environments in Kyushu, southwestern Japan, Zootaxa, 3271, 55-67, 2012.

Kulm, L. and Suess, E.: Relationship between carbonate deposits and fluid venting: Oregon accretionary prism, J. Geophys. Res., 95, 8899-8915, 1990.

Lalou, C., Fontugne, M., Lallemand, S. E., and Lauriat-Rage, A.: Calyptogena-cemented rocks and concretions from the eastern part of Nankai accretionary prism: Age and geochemistry of uranium, Earth Planet. Sc. Lett., 109, 419-429, 1992.

Lessard-Pilon, S. A., Podowski, E. L., Cordes, E. E., and Fisher, C. R.: Megafauna community composition associated with Lophelia pertusa colonies in the Gulf of Mexico, Deep-Sea Res. Pt. II, 57, 1882-1890, 2010.

Lietard, C. and Pierre, C.: Isotopic signatures $\left(\delta^{18} \mathrm{O} \& \delta^{13} \mathrm{C}\right)$ of bivalve shells from cold seeps and hydrothermal vents, Geobios, 42, 209-219, 2009.

Löffler, S.-B., Janssen R., Gürs, K. R., and Taviani, M.: The Genus Axinus Sowerby in the Mediterranean Basin (Bivalvia: Thyasiridae), J. Conchol., 38,5, 581-598, 2005.

Lott, C. and Zimmerman, J.: Do Mediterranean tubeworms like it hot? First discovery of tubeworms at hydrothermal vents outside of the Pacific Ocean, Recent News, Max-Plank-Institut für Mikrobiologie, available at: http://www.mpi-bremen.de/News_3. html, last access: 28 November 2012.

Lucente, C. and Taviani, M.: Chemosynthetic communities as fingerprints of submarine sliding linked fluid seepage, Miocene deep-sea strata of the Romagna Apennines, Italy, Palaeogeogr. Palaeocl. Palaeoecol., 227, 176-190, 2005.

Macdonald, I. R., Reilly, J. F., Guinasso, N. L., Brooks, J. M., Carney, R. S., Bryant, W. A., and Bright, T. J.: Chemosynthetic mussels at a brine-filled pockmark in the northern Gulf Of Mexico, Science, 248, 1096-1099, 1990.

Marcus, J., Tunnicliffe, V., and Butterfield, D. A.: Post-eruption succession of macrofaunal communities at diffuse flow hydrothermal vents on Axial Volcano, Juan de Fuca Ridge, Northeast Pacific, Deep-Sea Res. Pt. II, 56, 1586-1598, 2009.

Mazzotti, L., Segantini, S., Tramontana, M., and Wezel, F.-C.: Characteristics of pockmarks on the Jabuka trough floor (Central 
Adriatic Sea), Boll. Oceanol. Teor. Appl., 5, 237-250, 1987.

Micallef, A., Berndt, C., and Debono, G.: Fluid flow systems of the Malta Plateau, Central Mediterranean Sea, Mar. Geol., 284, 7485, 2011.

Minisini, D. and Trincardi, F.: Frequent failure of the continental slope: The Gela Basin (Sicily Channel), J. Geophys. Res., 114, F03014, doi:10.1029/2008JF001037, 2009.

Minisini, D., Trincardi, F., Asioli, A., Canu, M., and Foglini, F.: Morphologic variability of exposed mass-transport deposits on the eastern slope of Gela Basin (Sicily channel), Basin Res., 19, 217-240, 2007.

Mullineaux, L. S., Adams, D. K., Mills, S. W., and Beaulieu, S. E.: Larvae from afar colonize deep-sea hydrothermal vents after a catastrophic eruption, P. Natl. Acad. Sci., 107, 7829-7834, 2010.

Naehr, T. H., Rodriguez, N. M., Bohrmann, G., Paull, C. K., and Botz, R.: Methane-derived authigenic carbonates associated with gas hydrate decomposition and fluid venting above the Blake Ridge diapir, in: Proceedings of the Ocean Drilling Program, edited by: Paull, C. K., Matsumoto, R., Wallace, P. J., and Dillon, W. P., Scientific Results, 164, 285-300, 2000.

Newton, R. S., Cunningham, R. C., and Schubert, C. E.: Mud volcanoes and pockmarks: seafloor engineering hazards or geological curiosities? Offshore Technology Conf., Houston, TX, May 1980, Pap OTC 3729, 1980

Olu, K., Sibuet, M., Harmégnies, F., Foucher, J.-P., and FialaMédioni, A.: Spatial distribution of diverse cold seep communities living on various diapiric structures of the southern Barbados prism, Prog. Oceanogr., 38, 347-347, 1997.

Olu-Le Roy, K., Sibuet, M., Fiala-Médioni, A., Gofas, S., Salas, C., Mariotti, A., Foucher, J.-P., and Woodside, J.: Cold seep communities in the deep eastern Mediterranean Sea: composition, symbiosis and spatial distribution on mud volcanoes, Deep-Sea Res. Pt. I, 51, 1915-1936, 2004.

Olu-Le Roy, K., Caprais, J.-C., Fifis, A., Fabri, M.-C., Galéron, J., Budzinsky, H., Le Ménach, K., Khripounoff, A., Ondréas, H., and Sibuet, M.: Cold-seep assemblages on a giant pockmark off West Africa: spatial patterns and environmental control, Mar. Ecol., 28, 115-130, 2007.

Paull, C. K., Ussler III, W., Holbrook, W. S., Hill, T. M., Keaten, R., Mienert, J., Haflidason, H., Johnson, J. E., Winters, W. J., and Lorenson, T. D.: Origin of the pockmarks and chimney structures on the flanks of the Storegga Slide, offshore Norway, Geo-Mar. Lett., 28, 43-51, 2007.

Peckmann, J., Reimer, A., Luth, U., Hansen, B. T., Heinicke, C., Hoefs, J., and Reitner, J.: Methane-derived carbonates and authigenic pyrite from the northwestern Black Sea, Mar. Geol., 177, 129-150, 2001.

Reimer, P. J., Baillie, M. G. L., Bard, E., Bayliss, A., Beck, J. W., Blackwell, P. G., Bronk Ramsey, C., Buck, C. E., Burr, G. S., Edwards, R. L., Friedrich, M., Grootes, P. M., Guilderson, T. P., Hajdas, I., Heaton, T. J., Hogg, A. G., Hughen, K. A., Kaiser, K. F., Kromer, B., McCormac, F. G., Manning, S. W., Reimer, R. W., Richards, D. A., Southon, J. R., Talamo, S., Turney, C. S. M., van der Plicht, J., and Weyhenmeyer, C. E.: IntCal09 and Marine09 radiocarbon age calibration curves, $0-50,000$ years cal BP, Radiocarbon, 51, 1111-1150, 2009.

Ritt, B., Sarrazin, J., Caprais, J.-C., Nöel, P., Gauthier, O., Pierre, C., Henry, P., and Desbruyères, D.: First insights into the structure and environmental setting of cold-seep communities in the
Marmara Sea, Deep-Sea Res. Pt. I, 57, 1120-1136, 2010.

Roberts, H. H., Sassen, R., and Aharon, P.: Carbonates of the Louisiana Continental Slope, Offshore Technology Conference, 27-30 April 1987, Houston, Texas, 373-382, 1987.

Rodrigues, C. F. and Duperron S.: Distinct symbiont lineages in three thyasirid species (Bivalvia: Thyasiridae) from the eastern Atlantic and Mediterranean Sea, Naturwissenschaften, 98, 281287, 2011.

Rodrigues, C. F., Cunha, M. R., Olu, K., and Duperron, S.: The smaller vesicomyid bivalves in the genus Isorropodon (Bivalvia, Vesicomyidae, Pliocardiinae) also harbour chemoautotrophic symbionts, Symbiosis, 56, 129-137, 2012.

Sakai, H., Gamo, T., Kim, E. S., Tsutsumi, M., Tanaka, T., Ishibashi, J., Wakita, H., Yamano, M., and Oomori, T.: Venting of carbon dioxide-rich fluid and hydrate formation in mid-Okinawa trough backarc basin, Science, 248, 4959, 1093-1096, 1992.

Savini, A., Malinverno, E., Etiope, G., Tessarolo, C., and Corselli, C.: Shallow seep-related seafloor features along the Malta Plateau (Sicily channel - Mediterranean Sea): Morphologies and geo-environmental control of their distribution, Mar. Petrol. Geol., 26, 1831-1848, 2009

Scanlon, K. M. and Knebel, H. J.: Pockmarks in the floor of Penobscot Bay, Maine, Geo-Mar. Lett., 9, 53-58, 1989.

Shank, T. M., Herrera, S., Cho, W., Roman, C. N., and Croff Bell, K. L.: Exploration of the Anaximander mud volcanoes, Oceanography, 24, 22-23, 2011.

Sibuet, M. and Olu-Le Roy, K.: Cold seep communities on continental margins: structure and quantitative distribution relative to geological and fluid venting patterns, in: Ocean Margin Systems, edited by: Wefer, G., Billett, D., Hebbeln, D., Jørgensen, B. B., Schlüter, M., and Van Weering, T., Springer-Verlag, Berlin, Heidelberg, 235-251, 2002.

Somoza, L., Medialdea, T., Léon, R., Ercilla, G., Vázquez, J. T., lí Farran, M., Hernández-Molina, J., González, J., Juan, C., and Fernández-Puga, M. C.: Structure of mud volcano systems and pockmarks in the region of the Ceuta Contourite Depositional System (Western Alborán Sea), Mar. Geol., 332-334, 426, 2012.

Southward, E. C., Andersen, A. C., and Hourdez, A.: Lamellibrachia anaximandri $\mathrm{n}$. sp., a new vestimentiferan tubeworm (Annelida) from the Mediterranean, with notes on frenulate tubeworms from the same habitat, Zoosystema, 33, 245-279, 2011.

Stefanon, A.: Pockmarks in the Adriatic Sea? Abstracts, 2nd European Regional Meeting, International Association of Sedimentologists, Bologna, Italy, 189-192, 1981.

Stefanon, A., Rabitti, A., and Boldrin, A.: Gas-charged sediments and pockmarks in Adriatic Sea, Thalassia Jugoslavica, 19, 53$55,1983$.

Taviani, M.: The "Calcari a Lucina" macrofauna reconsidered: Miocene deep-sea faunal oases from Miocene-age cold vents in the Romagna Apennine, Italy, in: Submarine Hydrocarbon Vents in Modern and Ancient Environments, edited by: Aharon, P., Geo-Mar. Lett., 14, 185-191 1994.

Taviani, M.: Fluid venting and associated processes, in: Anatomy of an Orogen: the Apennines and Adjacent Mediterranean Basins, edited by: Vai, G. B. and Martini, I. P., Kluwer Academic Publishers, Great Britain, 351-366, 2001.

Taviani, M.: Abandoned and lost fishing devices as stepping-stones for deep water corals in the central Mediterranean Sea, Hermione 
Annual Meeting 2010, Malta 12-16 April, Conference Program and Abstract, 32, 2010.

Taviani, M.: The Deep-Sea Chemoautotroph Microbial World as Experienced by the Mediterranean Metazoans Through Time, in: Advances in Stromatolite Geobiology, edited by: Reitner, J., Qúeric, N.-V., and Arp, G., Lecture Notes in Earth Sciences, 131, 277-295, 2011.

Taviani, M.: Marine chemosynthesis in the Mediterranean Sea, in: The Mediterranean Sea: Its History and Present Challenges, edited by: Goffredo, S., Baader, H., and Dubinsky, Z., Springer, Science + Buisness Media Dordrecht, in press, doi:10.1007/97894-007-6704-1_5, 2013.

Taviani, M., Angeletti, L., Ceregato, A., Froglia, C., and Trincardi, F.: Recently discovered chemosynthetic assemblages from pockmark systems in the Strait of Sicily and Central Adriatic their bearing on composition, evolution and biogeography of the Mediterranean deep water cold seeps, IPC3 Chemosynthetic communities symposium; "Chemosynthetic communities: palaeoecology, systematics and evolutionary history", London, 28 June-3 July, 2010.

Taviani, M., Angeletti, L., and Trincardi, F.: Postglacial to modern benthic chemosynthetic communities from a pockmark field in the Strait of Sicily (Mediterranean Sea), 2nd Annual Meeting HERMIONE, 11-15 April 2011, Malaga (Spain), 2011.

Taylor, J. D. and Glover, E. A.: Evolutionary relationships of the bivalve family Thyasiridae (Mollusca: Bivalvia), monophyly and superfamily status, J. Mar. Assoc. UK, 87, 565-574, 2007.

Taylor, J. D. and Glover, E. A.: Chemosymbiotic bivalves, in: The Vent and Seep Biota, Topics in Geobiol 33, edited by: Kiel, S., Springer Science-Business Media Dordrecht, 2010.
Teichert, B. M. A., Eisenhauer, A., Bohrmann, G., Haase-Schramm, A., Bock, B., and Linke, P.: U/Th systematics and ages of authigenic carbonates from Hydrate Ridge, Cascadia Margin: recorders of fluid flow variations, Geochim. Cosmochim. Ac., 67, 3845-3857, 2003.

Trincardi, F. and Argnani, A.: Gela submarine slide: a major basinwide event in the Plio-Quaternary foredeep of Sicily, Geo-Mar. Lett., 10, 13-21, 1990.

Trincardi, F., Cattaneo, A., Correggiari, A., and Ridente, D.: Evidence of soft sediment deformation, fluid escape, sediment failure and regional weak layers within the late Quaternary mud deposits of the Adriatic Sea, Mar. Geol., 213, 91-119, 2004.

Tyler, P. A. and Young, C. M.: Dispersal at hydrothermal vents: a summary of recent progress, Hydrobiologia, 503, 9-19, 2003.

Verdicchio, G. and Trincardi, F.: Mediterranean shelf-edge muddy contourites: example from Gela and South Adriatic Basins, GeoMar. Lett., 28, 137-151, 2008.

von Rad, U., Rösch, H., Berner, U., Geyh, M., Marchig, V., and Schulz, H.: Authigenic carbonates derived from oxydized methane vented from the Makran accretionary prism off Pakistan, Mar. Geol., 136, 55-77, 1996.

Werne, J. P., Haese, R. R., Zitter, T., Aloisi, G., Bouloubassi, I., Heijfs, S., Fiala-Médiconi, A., Pancost, R. D., Sinninghe Damsté, J. S., de Lange, G., Forney, L. J., Gottschal, J. C., Foucher, J. P., Mascle, J., and Woodside, J.: Life at cold seeps: a synthesis of biogeochemical and ecological data from Kazan mud volcano, eastern Mediterranean Sea, Chem. Geol., 205, 367-390, 2004.

Young, C. M.: Reproduction, development and life-history traits, in: Ecosystems of the Deep Oceans, Ecosystems of the World, edited by: Tyler, P. A., Elsevier, 28, 381-384, 2003. 